This PDF is a selection from an out-of-print volume from the National Bureau of Economic Research

Volume Title: Trade Policy Issues and Empirical Analysis

Volume Author/Editor: Robert E. Baldwin, ed.

Volume Publisher: University of Chicago Press

Volume ISBN: 0-226-03607-3

Volume URL: http://www.nber.org/books/bald88-2

Publication Date: 1988

Chapter Title: U.S. and Swedish Direct Investment and Exports

Chapter Author: Magnus Blomstrom, Robert E. Lip, Ksenia Kulchycky

Chapter URL: http://www.nber.org/chapters/c5853

Chapter pages in book: (p. 257 - 302) 
III Determining the Relationship between Foreign Direct Investment and Exports 
This Page Intentionally Left Blank 


\title{
U.S. and Swedish Direct Investment and Exports
}

\author{
Magnus Blomström, Robert E. Lipsey, \\ and Ksenia Kulchycky
}

The effect of foreign production by a country's firms on the home country's exports continues to be a puzzle after many years of controversy and a considerable amount of empirical research. Theoretical models of direct foreign investment typically treat the size of a market as exogenous and a company's share of a market as a function of its firm-specific capital. The decision as to whether to produce abroad is then a matter of choosing among possible methods of serving the foreign market, including exporting from the home country, producing abroad, and licensing others to produce the firm's product. That decision will depend on the nature of the firm's intangible assets, on transport costs, economies or diseconomies of scale, barriers to trade and other government regulations, on factor prices at home and in other countries,

Magnus Blomström is associate professor of economics at the Stockholm School of Economics and a research economist at the National Bureau of Economic Research. Robert E. Lipsey is professor of economics at Queens College and the Graduate Center of the City University of New York and a research associate of the National Bureau of Economic Research. Ksenia Kulchycky is a Ph.D. candidate in the Department of Economics of the University of Pennsylvania.

This research is part of the NBER program in International Studies. Magnus Blomström's part of the research took place while he was a member of the staff of the Industriens Utredningsinstitut of Stockholm. Robert Lipsey's research was supported first by an SSRC-Fulbright Fellowship and later by a PSC-CUNY grant and a grant of computer time from the City University of New York. The authors are grateful to the Industriens Utredningsinstitut and the Bureau of Economic Analysis of the U.S. Department of Commerce for use of their data and to Robert Baldwin, Jeffrey Zax, and participants in the NBER Conference on Trade Policy Issues and Empirical Analysis, particularly the discussants, Steven J. Matusz and John Mutti, for useful comments and suggestions. Linda Molinari assisted with statistical work and computer programming and James Hayes and Rosa Schupbach with the preparation of the manuscript. 
as well as on the need to adapt the product to differences among markets in the characteristics demanded. This more or less standard view of the multinational firm implies that production in a market is a substitute for production at home for export to that market.

A more neutral viewpoint would be to regard a firm's share of a market as being at least partly dependent on whether it produces there, even though local production does not affect the demand for the firm's products. That would be the case, for example, if a product were totally nontradable: that may be true for some services, such as tourism or medical care. If all the firm's products were nontradable, there could, of course, be no effect of overseas production on exports. A more interesting example would be a firm that can increase its market share in a country by producing there, because local production reduces the cost of supplying the market. If that local production requires some input from the parent, such as components, it might raise or lower parent exports, depending on the size of the gain in market share and the importance of parent input in the affiliate's output.

A third possibility is that a firm's production in a host country increases that country's demand for the firm's products. In that case, higher production abroad by a country's firms would be more likely to lead to larger home country exports. That is most obvious if the production abroad is in activities ancillary to exporting, such as sales and service operations. A positive effect of production abroad on home country exports could also result if production of one part of a parent company's range of products familiarizes a market with the parent company's name and reputation. Production in a country by a multinational might also raise that country's demand for the product in general, rather than for only the output of the multinational firm. That might be the case, for example, if a company like Coca Cola entered a country and advertised heavily. The demand for cola drinks might increase enough to open the market to local or other foreign producers.

With all these possibilities, the assumption of fixed market shares for a parent firm, convenient though it is, seems inappropriate to us. Furthermore, even if a firm's overseas production added to exports by the parent, for one of the reasons mentioned above, that addition might be at the expense of exports by rival companies in the home country. For this reason we examine the effects of production abroad by a country's firms on the home country's exports rather than on the exports of the parents themselves.

We analyze the effects of foreign production on home country exports, using cross-section data from Sweden and the United States. In addition, for Swedish exports, we also study the determinants of changes over time in exports to each destination. 


\subsection{Earlier Empirical Findings}

Despite the implications of theoretical models of direct investment, empirical studies have rarely observed substitution between overseas production and exports. A cross-sectional study for 1970 covering fourteen industries, based on foreign production data for about two hundred of the larger U.S. investors, found only positive coefficients among those that were significant in equations in which U.S. exports to a country in an industry were related to U.S. companies' production in that country and industry as well as to other variables (Lipsey and Weiss 1981). At the same time, coefficients for U.S. companies' production were mostly negative in equations explaining exports to each country by other industrial countries. There was weaker evidence, from data on numbers of affiliates, that investment by countries other than the United States was negatively related to U.S. exports, and positively related to exports by other countries. The positive (complementary) relationship between U.S.-owned production and U.S. exports was also evident in equations for individual U.S. firms' exports, based on the same data (Lipsey and Weiss 1984).

Bergsten, Horst, and Moran (1978), using published IRS and U.S. Department of Commerce data, concluded that "the relation between foreign investment and exports or imports is largely haphazard" (p. 97), although they suggested that there is a noticeable complementarity for investment up to a certain level, because most of the initial investment goes into marketing and assembly.

The most elaborate examination of trade investment relationships for individual firms has been performed by Swedenborg $(1979,1982)$ for Swedish multinationals. OLS (ordinary least squares) equations relating the ratio of exports to home production to the ratio of foreign to home production across all industries showed a positive and significant influence of foreign production on firm exports, and of foreign production in a country on firm exports to the country. A 2SLS (twostage least squares) estimate of the relationship found it statistically insignificant, although the coefficients across all firms, and across all firms and countries, did not change greatly. As compared with those in the OLS equations, they fell by 25 percent to 30 percent. Equations confined to firms with more than five affiliates produced lower coefficients in OLS equations, and more of a decline in 2SLS.

Swedenborg (1982) also combined data from four Swedish surveys, again using $2 S L S$, and found that each increase by $\$ 10$ of foreign production in a country produced an increase of exports to that country by the parent company of $\$ 1$. That $\$ 1$ increase was the net outcome of $\$ 1.20$ added to exports to the affiliate and $\$ .20$ subtracted from exports to nonaffiliates in the country. 


\subsection{Estimating the Effects of Foreign Production}

The fear that foreign production by a country's firms means the export of jobs to other countries is an old one. Bergsten, Horst, and Moran (1978) trace the discussion in the United States back to the 1920s; the discussion occurred despite the fact that much of the flow of U.S. investment at that time was in public utilities, not likely to be competitive with U.S. production.

While the idea of exporting jobs in the aggregate is a fuzzy one, and while economists have not generally considered the maximization of commodity exports to be a sensible objective for economic policy, these fears have led to recurrent efforts to measure the effect that U.S. firms' overseas production has on exports and to proposals for government action to hinder the growth of such production.

There are several possible ways of defining the proposition that production overseas by a country's firms substitutes for, or is complementary to, exports by the country or by the parent firms themselves. Each way is associated with a different implied model of the behavior of firms or a different policy question.

The simplest, if unrealistic, view might be that the factors determining the location and extent of affiliate production in a country are unrelated to the factors that determine parent exports to a country. This would be the case if affiliates were handed out to parents in a lottery. What might amount to much the same thing would be if the decision to establish an affiliate in a country were a very long-term one, and virtually permanent once made, while the export decision was a short-term one, easily adjusted to contemporary circumstances. Then, even if the existence and size of an affiliate reflected the same influences, such as exchange rates or price levels, which also played an important role in determining trade flows, the investment and the exports would reflect these influences from different periods. In that case, we could still interpret a coefficient for affiliate production, for example, in an equation explaining exports from the home country as representing the effect of affiliate production on exports.

The persistent problem in these analyses is the likelihood that the variables that determine investment in a country and affiliate production are the same as the ones determining trade flows. Some of the obvious ones, such as host country income and income per capita, can be included in the equation for trade flows to avoid attributing their effect to affiliate activity. But the risk that always remains is that there are unaccounted-for variables-such as host country regulation-that influence both investment and trade, and that we attribute their effects to investment. 
There have been various attempts to escape this problem. The most obvious way is to include all relevant explanatory variables in the trade equation, but one can never be sure that there are not important additional variables omitted. In studies of exports by Swedish multinationals, Swedenborg $(1979,1982)$ used 2SLS, with the first-stage equation estimating affiliate production and the second-stage equation estimating parent exports as a whole and parent exports to individual countries. One difficulty was that the first-stage equation explained little of the variation in affiliate production. Consequently, a good deal of what may have been relevant variation in affiliate production was omitted in the second stage.

Lipsey and Weiss $(1981,1984)$ attempted to escape the problem by including a larger number of variables in the OLS equations, by working within fairly detailed industries, and by examining the relationships of affiliate production, not only to home-country exports but also to exports by others. The idea behind the last procedure was that it was likely to reveal some spurious relationships based on omitted characteristics of countries, provided that the omitted variables did not produce opposite effects on U.S. exports and exports by others.

Another method of dealing with the simultaneity issue, which we have tried in this chapter, is to study not only the levels of exports at one time, but also changes over time in home country exports to each destination. The assumption involved is that the effects of the most troublesome unaccounted-for factors that simultaneously influence investment and exports do not determine changes in these, or that their influence is incorporated in the initial levels of affiliate production and exports. We do not believe that such a cross section of changes over time has been tried before.

\subsection{Trade Equations}

The equations explaining U.S. and Swedish exports for each industry group are related to the trade equations of the type discussed in Leamer and Stern (1970) and used in studies by Chenery (1960), Linneman (1966), and others. They do differ, however, in a couple of respects. One is that they all relate to exports from one country and therefore do not involve any exporting-country variables. A second is that we use GDP and GDP per capita rather than GDP and population (only two of the three-income, population, and income per capita-can be used, because any two determine the third). A third difference is that we have dropped the distance variable, typically used as a measure of trade resistance, since it made little difference to the results and we 
needed to economize on independent variables. The implied trade equation for each industry is then

$$
E X P_{i j}=f\left(G D P_{j}, G D P C_{j}\right),
$$

where $E_{X X} P_{i j}$ equals exports from the U.S. in 1982 or Sweden in 1978 to country $j$ in products of industry $i ; G D P_{j}$ equals real GDP of country $j$ in 1978 or 1982 in international prices (see appendix); and $G D P C_{j}$ equals real GDP per capita of country $j$ in 1978 or 1982 in international prices.

We expect the coefficients for GDP to be positive, although one can imagine cases in which the expected influence of aggregate income on the aggregate demand for the product is more than offset by its influence on supply. For example, that may be the case in an industry in which economies of scale are of great importance and large markets are the preferred locations for production, so that while overall demand in a country is high, import demand is low. Coefficients for GDPC may be either positive or negative. Among the demand-side influences, a high income elasticity of demand should mean high demand in countries with high per capita income, given the aggregate GDP, and therefore a positive coefficient for GDPC. A low income elasticity should produce a negative coefficient. Obvious missing variables are tariff levels, for which we do not have information for a sufficient number of countries, and restrictions on imports or inducements to exports by affiliates, which are possibilities for further research. There are no industry characteristics, such as appear in some other studies of this issue, because each equation includes data for only one industry group.

To these trade equations we add several variables representing affiliate activity or production. These are $N S_{i j}$, which equals net sales of affiliates in industry $i$ located in country $j$ (sales minus imports from the home country); $N L S_{i j}$, which equals net local sales-sales of affiliates in industry $i$ located in country $j$ to buyers in country $j$, minus the portion of these sales accounted for by imports (that amount is estimated assuming that the ratio of imports to sales is the same for sales in the host country as for sales to other countries); and $N E S_{i j}$, which equals net export sales-sales of affiliates in industry $i$ located in country $j$ to buyers outside country $j$, minus the portion of these sales accounted for by imports, estimated as for $N L S$.

We have no prior expectations for either net sales or net local sales. They include a mixture of influences in opposite directions. To the extent that affiliate production substitutes for exports from the United States or Sweden by either the parents or other firms, the effect on exports should be negative. That would be true if affiliate production of finished products substituted for exports of finished products, but also even if affiliate assembly of products substituted for only the final 
stages of output, provided that the U.S. or Swedish companies' share in the country's consumption was a fixed amount determined by country size and other country variables. Even if production in a host country increased exports of components or of other finished products by the parent, the effect on home country exports as a whole could be negative if some production replaced export sales by other U.S. or Swedish companies.

On the other side, if production in a host country by a U.S or Swedish company increased the size of that country's market for the products of that company's industry, or if it raised the company's share of the market even without increasing the size of the market, the effect on home country exports would be positive, provided that the increase in share came at the expense of local or other foreign companies rather than at the expense of other U.S. or Swedish companies. The positive effects could be on home country exports of raw materials or components or on home country exports of other finished products. The effect on finished products might occur if local production familiarized the host country with the parent's brand name or with U.S or Swedish goods more generally. The positive effect on home country exports may be enhanced by the fact that some of the affiliate production, even in affiliates classified as manufacturing, consists of distribution and service activities.

As between net sales and net local sales, we would expect negative coefficients to be more likely in the latter case. To the extent that affiliate production is for export rather than for local sale, it should not substitute for home country exports to the host country, even if it competes with home country exports to other countries. Thus, when we treat production for export separately, we expect the coefficient on net export sales to be positive.

\subsubsection{Effects of Swedish Affiliate Production}

Our examination of the consequences of Swedish firms' overseas production is based on the same set of data on multinational firms as was used by Swedenborg (1982), but in more aggregated form. Furthermore, it focuses on aggregate Swedish exports in each industry, including exports by nonmultinational firms, rather than on exports by the parent firms themselves. The data cover ten individual industries (see appendix for a description of the data). We have used equations for only the seven industries in which there are at least ten countries with Swedish-owned production.

The impact on Swedish exports of overseas production by Swedish firms is described by the set of coefficients for affiliate production in equations explaining Swedish exports to a country by GDP and GDP per capita, as in the trade equations described above, but adding a 
variable for being a Nordic country (Denmark, Finland, and Norway). We also performed a 2 SLS regression on the Swedish data where the first-stage equations included a dummy variable for EEC membership. We expected the coefficients for GDP and GDP per capita, as well as that for being a Nordic country, to be positive (see table 9.1).

In the OLS regressions, all the coefficients are positive, implying that, other things equal, greater production by Swedish affiliates in a country is associated with larger exports from Sweden. The range of coefficients is wide, from 230 kronor of exports per thousand kronor of production in the host country, to exports greater than the host country production. There is no evidence here that host country production substitutes for exports from Sweden.

In the results there is some suggestion of unaccounted-for curvilinearity in the relationship, in the fact that the intercepts, supposedly showing the exports that would take place without any Swedish-owned production in the country, are mostly negative and fairly large, although they are not statistically significant (see appendix, table 9.A.1).

The coefficients in the 2SLS regressions are in general much larger than those in the OLS equations, although the story they tell is similar. All the coefficients in the 2SLS analysis are positive, and two of them indicate that a krona of Swedish-owned production in a foreign country draws in more than a krona of Swedish exports.

Table 9.1 Coefficients for Affiliate Net Sales in Swedish Export Equations, 1978

\begin{tabular}{lcc}
\hline Industry Group & OLS & 2SLS \\
\hline Paper products & .229 & .435 \\
& $(4.98)$ & $(4.09)$ \\
Chemicals & .836 & 3.511 \\
& $(4.05)$ & $(3.09)$ \\
Metal manufacturing & .379 & .500 \\
& $(4.43)$ & $(4.34)$ \\
Nonelectrical machinery & .359 & .368 \\
& $(12.9)$ & $(9.05)$ \\
Electrical machinery & .086 & .516 \\
& $(1.40)$ & $(1.15)$ \\
Transport equipment & .312 & .921 \\
& $(3.49)$ & $(2.85)$ \\
Other manufacturing & 1.137 & 2.490 \\
& $(6.64)$ & $(4.58)$ \\
\hline
\end{tabular}

Sources: Tables 9.A.1 and 9.A.2.

Notes: $\mathbf{t}$-Statistics are in parentheses. Equations include, as independent variables, GDP, GDPC, a dummy variable for being a Nordic country, and Swedish manufacturing affiliate net sales. The instrument variable in the 2SLS is a variable for EEC membership. 
We were able to distinguish affiliate production for local sale in the host country (net local sales) for only five industries. The result of substituting net local sales for net sales in these five industries is shown in table 9.2. The substitution produces larger coefficients for affiliate sales in most cases, but only two of the differences are substantial.

On the whole, then, while we would hesitate to place great weight on the estimated size of the coefficients, we think the evidence for a positive relationship is reasonably strong. There is certainly no sign of any negative relationship in this cross section.

Another way of looking at the relation between foreign production and exports is to relate changes in exports to a country, in each industry group over a period, to the initial levels of exports to and affiliate activity in that country, and to changes in real income and affiliate activity. We estimated the following equations:

$$
\begin{aligned}
& \Delta E X P_{i j}=f\left(\Delta G D P_{j}, E X P 70_{i j}, N S 70_{i j}\right), \text { and } \\
& \Delta E X P_{i j}=f\left(\Delta G D P_{j}, E X P 70_{i j}, \Delta N S_{i j}\right),
\end{aligned}
$$

where $\Delta E X P_{i j}$ equals changes in exports from Sweden to country $j$ in products of industry $i, 1970-78$ (thousand kronor); $\triangle G D P_{j}$ equals changes in real GDP of country $j, 1970-78$ (millions of dollars); $E X P 70_{i j}$ equals exports from Sweden to country $j$ in products of industry $i$ in 1970 (thousand kronor); $\Delta N S_{i j}$ equals changes in affiliates' net sales, $1970-78$ (thousand kronor); and $N S 70_{i j}$ equals affiliates' net sales in 1970 (thousand kronor).

The variable for exports in the beginning of the period should incorporate the effects of not only the factors that we controlled for in Export Equations, 1978

\begin{tabular}{lcc}
\hline Industry Group & Net Sales & Net Local Sales \\
\hline Paper products & .217 & .351 \\
& $(2.11)$ & $(2.79)$ \\
Chemicals & .809 & .870 \\
& $(2.29)$ & $(2.32)$ \\
Metal manufacturing & .330 & .268 \\
& $(1.59)$ & $(.80)$ \\
Nonelectrical machinery & .336 & .508 \\
& $(5.87)$ & $(6.32)$ \\
Electrical machinery & .083 & .085 \\
& $(1.11)$ & $(1.12)$ \\
\hline
\end{tabular}

Source: Table 9.A.3.

Note: Numbers in parentheses are t-statistics. 
cross-section equations above, but also most of the unaccounted-for variables that we mentioned.

Initial foreign production and changes in it are included in separate regressions. The variable for the initial production position should tell us whether, as time goes by, affiliates substitute their own production for imports from the home country. In other words, do Swedish exports, given their initial level, increase less to countries with higher initial levels of Swedish-owned production? We should note that this is a different question from the one studied by Swedenborg $(1979,1982)$, which is whether the proportion of local sales that a company makes from local production changes with the age of the affiliate. The shortor medium-run effects of foreign production on exports should be reflected in the coefficients for changes in affiliate production. In other words, do Swedish exports increase less, given their initial level, to countries where Swedish-owned production increases more?

The results from these regressions are shown in table 9.3 These results strengthen our earlier impressions of a predominantly positive influence of affiliate production on home country exports. The variable for the initial level of affiliate production generally carries a positive and strongly significant coefficient. Metal manufacturing is the main exception. There is thus not much evidence here that Swedish firms'

Table 9.3 Coefficients for Affiliate Net Sales in 1970 and Changes in Net Sales in Swedish Export Change Equations, 1970-78

\begin{tabular}{lrr}
\hline Industry Group & NS70 & $\Delta$ NS \\
\hline Paper products & .201 & .058 \\
& $(1.36)$ & $(1.62)$ \\
Chemicals & .448 & .179 \\
& $(2.34)$ & $(1.60)$ \\
Metal manufacturing & -.271 & -.158 \\
& $(2.60)$ & $(3.19)$ \\
Nonelectrical machinery & .122 & .062 \\
& $(2.27)$ & $(1.81)$ \\
Electrical machinery & .282 & -.132 \\
& $(1.04)$ & $(1.46)$ \\
Transport equipment & 1.899 & .276 \\
& $(2.71)$ & $(3.64)$ \\
Other manufacturing & .836 & .444 \\
& $(2.44)$ & $(4.65)$
\end{tabular}

Source: Table 9.A.4.

Notes: Numbers in parentheses are t-statistics. Both equations based on net sales in 1970 (NS 70), and equations based on changes in net sales, 1970-78 ( $\Delta$ NS) include, as independent variables, Swedish exports to a country in 1970, in thousands of Swedish kronor, and the percentage change in real GDP between 1970 and 1978. 
production in a country tends to reduce the country's subsequent imports from Sweden. The higher the level of Swedish-owned production in 1970, the larger the increase in Swedish exports between 1970 and 1978. The coefficient for changes in affiliate production is positive in five of the seven industries, and significantly different from zero at the 5 percent level in three of these. Only in metal manufacturing do we again find a negative and significant coefficient. On the whole, the larger the growth in Swedish-owned production in the host country, the greater the growth in exports from Sweden. This suggests a dominance of complementarity rather than of substitution between overseas production and exports.

\subsubsection{Effects of U.S. Affiliate Production}

For the United States we show two sets of equations and results. The U.S. data for majority-owned affiliates were available at a much more detailed industry level than the Swedish data: thirty-four industries, of which we show results for the thirty industries in which we had at least fifteen countries with some affiliate net sales. The second set of equations, in which we add data for minority-owned affiliates, was run for only seven broad industry groups.

The coefficients for various measures of production by majorityowned U.S. affiliates in U.S. export equations are summarized in table 9.4. The equations with only one affiliate production variable indicate that in about 80 percent of the industries, production in a country by majority-owned U.S affiliates was either unrelated to or positively related to exports by U.S firms in the same industry. In industries for which there was a statistically significant relationship and, more broadly,

Table 9.4 Summary of t-Statistics for Coefficients of Affiliate Production in U.S. Export Equations, 1982 (30 industries)

\begin{tabular}{|c|c|c|c|c|}
\hline & \multicolumn{2}{|c|}{$\begin{array}{l}\text { Equations with One } \\
\text { Production Variable }\end{array}$} & \multicolumn{2}{|c|}{$\begin{array}{l}\text { Equations with Two } \\
\text { Production Variables }\end{array}$} \\
\hline & $\begin{array}{l}\text { Net } \\
\text { Sales }\end{array}$ & $\begin{array}{c}\text { Net } \\
\text { Local Sales }\end{array}$ & $\begin{array}{c}\text { Net } \\
\text { Local Sales }\end{array}$ & $\begin{array}{c}\text { Net } \\
\text { Export Sales }\end{array}$ \\
\hline \multicolumn{5}{|l|}{ Coefficients with $t \geq 1$} \\
\hline \multicolumn{5}{|l|}{ Positive } \\
\hline$t \geq 2$ & 7 & 7 & 3 & 6 \\
\hline $1 \leq \mathrm{t}<2$ & 6 & 8 & 11 & 3 \\
\hline \multicolumn{5}{|l|}{ Negative } \\
\hline$t \geq 2$ & 4 & 5 & 5 & 1 \\
\hline $1 \leq t<2$ & 1 & 1 & 1 & 1 \\
\hline Coefficients with $t<1$ & 12 & 9 & 10 & 19 \\
\hline
\end{tabular}

Sources: Tables 9.A.5-9.A.7. 
in all industries in which the coefficient for production was at least as large as its standard error, most of the coefficients were positive, suggesting complementarity between U.S. exports and U.S.-owned production in a country, rather than substitution of one for the other. The five industries in which there were negative coefficients twice their standard errors, suggesting some substitution of host country production for U.S. exports, were (1) other foods, (2) drugs, (3) industrial chemicals, (4) primary nonferrous metals, and (5) lumber, wood, furniture, and fixtures. The negative coefficient for drugs is particularly surprising because it contradicts the strong finding of complementarity for this industry in Lipsey and Weiss (1981).

When we separate production in each country into production for local sale and production for export, we find, as we expect, that indications of substitution are almost entirely confined to production for local sale (net local sales). For most industries, we find that production for export from the host country has no visible influence on U.S. exports to the host country, and where we do find a relationship, it is a positive one in the great majority of cases. The effects of production for local sale are not as clear. There are more instances of negative coefficients than of positive ones twice their standard errors, but the whole group of coefficients at least equal to their standard errors shows a large majority of positive (complementary) relationships. Evidence of substitution still is confined to a small minority of the thirty industries.

\subsection{Production by Minority-Owned Affiliates}

Most analyses of trade investment relationships have concentrated on majority-owned affiliates. The main reason is probably the paucity of data on affiliates that are 50 percent or less owned by the parent. The Swedish data used above include virtually no information on these affiliates, and the U.S. surveys have exempted them from large parts of the questionnaire, and particularly from the trade questions. One justification for that exemption is that the parent firms often would not know the answers and would not have the same ability to compel cooperation from minority-owned affiliates as from majority-owned affiliates.

The omission of affiliates 50 percent or less owned would be relatively harmless if they were randomly scattered over the world and over industries. We know, however, that they are not. They are virtually the only U.S. affiliates in Japan, for example, and are of considerable importance in that country. Their importance is also associated with industry and country characteristics, such as the technological level of the industry and the income level of the country, both characteristics often used in the examination of trade investment relationships. 
Aside from its interaction with some of the explanatory variables, production by minority-owned affiliates (for convenience, we will refer to minority ownership, even though it includes a substantial number of cases of 50 percent ownership) might have different effects on trade from those of production by majority-owned affiliates. One possibility is that the effects would be simply a diluted version of those associated with majority ownership, because they are shared among several owners, some of which are often not U.S. firms. On the other hand, production by minority-owned affiliates might have a stronger effect on parent trade, because minority ownership is resorted to in cases in which the parent would otherwise be barred from a market, either because the host country has particularly stringent barriers to imports or because the parent company does not have a very large technological advantage over other firms. Minority ownership might represent a price for entry into a market more often than does majority ownership.

Because minority-owned affiliates did not receive the questionnaire on the disposition of their sales, we cannot calculate net local sales or net export sales for them. The activity measure for them in all the equations is net sales, whatever the measure used for majority-owned affiliates. Because these equations are based on published data, we are also limited here to equations for six industry groups (using net sales for majority-owned affiliates) or for four industry groups (using net local sales for majority-owned affiliates) instead of the thirty industries used earlier.

The coefficients for production by minority-owned affiliates in equations including various versions of production by majority-owned affiliates are summarized in table 9.5. Whatever the measure of production we use for majority-owned affiliates, the coefficients for production by minority-owned affiliates are all positive (table 9.A.9). Only a few are statistically significant at the 5 percent level, but almost all are larger than their standard errors. Thus, minority-owned affiliates' activity seems to be more clearly complementary to exports from the United States than that of majority-owned affiliates.

Adding the variable for production by minority-owned affiliates to the equations has another effect: it strengthens the case for complementarity between production by majority-owned affiliates and exports from the United States, as seen in table 9.5. In the equations for these broad industry groups that did not include any variable for minorityowned production, the results showed substitution between production in majority-owned affiliates and exports from the United States as often as, or more often than, complementarity. When the variable for production by minority-owned affiliates was included, the coefficients for production by majority-owned affiliates shifted toward showing greater evidence for complementarity. Thus, the addition of data for minority- 
Table 9.5

Summary of t-Statistics for Coefficients of Production by MajorityOwned Affiliates in U.S. Export Equations, With and Without Production by Minority-Owned Affiliates, 1982 (6 industry groups)

\begin{tabular}{lll}
\hline & $\begin{array}{c}\text { Production by } \\
\text { Minority-Owned } \\
\text { Affiliates }\end{array}$ \\
\cline { 2 - 3 } & Excluded & Included \\
\hline Coefficients with $t \geq 1$ & & \\
Positive & & 7 \\
$t \geq 2$ & 1 & 2 \\
$1 \leq t<2$ & 5 & 3 \\
Negative & & \\
$t \geq 2$ & 3 & 1 \\
$1 \leq t<2$ & 2 & 5 \\
Coefficients with $t<1$ & 7 & \\
\hline
\end{tabular}

Sources: Tables 9.A.8 and 9.A.9.

owned affiliates strengthens the case for a positive effect of affiliates' production on home country exports.

In view of the always present possibility that some missing variable could explain both the level of U.S. affiliate production in and the level of U.S. exports to a country, we would like to have information on production in each host country by affiliates from countries other than the United States. We could then test whether exports by each home country were reduced by the production of other countries' affiliates, while they were increased by the production of their own affiliates. Such a relationship was found in somewhat crude data for 1970 by Lipsey and Weiss (1981).

Unfortunately, we do not have recent data on the presence of, or production by, non-U.S. affiliates in each country. As the closest approach we could make to such a test, we have related exports to a host country by countries other than the United States to production in the host country by U.S. affiliates. If U.S.-owned production serves to increase the U.S. share in a country's imports without expanding the level of imports, U.S.-owned production should be negatively related to exports by other countries to the host countries. If U.S.-owned production increases U.S. sales by expanding markets in host countries, we might find no relation to exports by other countries or even a positive one. A positive relationship could also reflect an expansion of a U.S. company's exports to the host country from its operations in countries outside the United States. A more troublesome implication of a positive coefficient could be that it shows we have not successfully accounted for important determinants of a host country's imports, such 
as the activity of non-U.S. affiliates or, more generally, an open trade and investment regime.

The results, summarized in table 9.6, are not reassuring. The coefficients in equations for thirty industries, using net sales as the affiliate production measure, are all positive and all but a few are more than twice their standard errors. One might expect local sales by U.S. affiliates, rather than total sales, to be most closely associated with exports to that market by other countries. The use of net local sales leaves the predominance of positive relationships intact, although it reduces the frequency of strong positive relationships between U.S. affiliate production in a country and that country's imports from others.

A possible explanation for the apparently persistent positive coefficient is suggested by the equations using both net local sales and net export sales by U.S. affiliates as explanatory variables. Almost half of the coefficients for net local sales are close to zero, while most of the rest are positive. The coefficients for net export sales are overwhelmingly positive and statistically significant. The most likely explanation, we suspect, is that high export sales by affiliates, in particular, reflect policies that attract direct investment in production by firms from both the United States and other countries, and the imports associated with this production. The U.S. affiliate production, and particularly U.S. affiliate production for export, is therefore acting, to some extent, as a proxy for the openness of a country's trade and investment regime and for the presence of non-U.S. affiliates.

Table 9.6 Summary of t-Statistics for Coefficients of U.S. Affiliate Production in Non-U.S. Export Equations, 1982 (30 industries)

\begin{tabular}{|c|c|c|c|c|}
\hline & \multicolumn{4}{|c|}{ Measure of Affiliate Production } \\
\hline & \multicolumn{2}{|c|}{$\begin{array}{l}\text { Equations with One } \\
\text { Production Variable }\end{array}$} & \multicolumn{2}{|c|}{$\begin{array}{l}\text { Equations with Two } \\
\text { Production Variables }\end{array}$} \\
\hline & $\begin{array}{l}\text { Net } \\
\text { Sales }\end{array}$ & $\begin{array}{l}\text { Net Local } \\
\text { Sales }\end{array}$ & $\begin{array}{l}\text { Net Local } \\
\text { Sales }\end{array}$ & $\begin{array}{l}\text { Net Export } \\
\text { Sales }\end{array}$ \\
\hline \multicolumn{5}{|l|}{$\begin{array}{l}\text { Coefficients with } t \geq 1 \\
\text { Positive }\end{array}$} \\
\hline$t \geq 2$ & 27 & 22 & 10 & 18 \\
\hline $1 \leq t<2$ & 1 & 6 & 6 & 5 \\
\hline $\begin{array}{c}\text { Negative } \\
t \geq 2\end{array}$ & & & & \\
\hline $1 \leq t<2$ & & & 1 & 2 \\
\hline Coefficients with $t<1$ & 2 & 2 & 13 & 5 \\
\hline
\end{tabular}

Sources: Tables 9.A.10-9.A.12. 
Somewhat the same set of relationships can be observed in equations for the major industry groups, where we can include information on production by U.S. minority-owned affiliates (table 9.7). In the equations in which net sales are used as a production measure, the coefficients for majority-owned affiliates are all positive and mostly significant at the 5 percent level. Those for minority-owned affiliates are almost all negative, however. Two are statistically significant, and two others are larger than their standard errors. Thus, there is evidence that production by minority-owned U.S. affiliates does substitute for a country's imports from countries other than the United States.

Some further hint of what we may be missing by omitting minority affiliates from our earlier calculations can be gleaned from the equations in table 9.8. These separate production by majority-owned affiliates into production for local sale and production for export and include minority affiliate net sales. The large positive coefficients in the equations for exports by other countries are associated mainly with U.S. affiliates' production for export. We would not expect these to compete with foreign countries' exports to the production location, and we suspect they act as a proxy for production by foreign countries' affiliates, as mentioned earlier. Production by U.S. minority-owned affiliates in two industries and production for local sale by majority-owned affiliates in one industry do appear to substitute for imports from countries other than the United States.

Table 9.7 Coefficients for Production by Majority-Owned and MinorityOwned U.S. Affiliates in Non-U.S. Export Equations, 1982

\begin{tabular}{lcc}
\hline Industry Group & $\begin{array}{c}\text { Production of } \\
\text { Majority-Owned } \\
\text { Affiliates }\end{array}$ & $\begin{array}{c}\text { Production of } \\
\text { Minority-Owned } \\
\text { Affiliates }\end{array}$ \\
\hline Foods & 585 & $-2,194$ \\
Chemicals & $(1.7)$ & $(1.8)$ \\
Metals & 255 & $-2,446$ \\
Nonelectrical machinery & $(3.5)$ & $(4.6)$ \\
Electrical machinery & 2,279 & $-2,252$ \\
Transport equipment & $(4.1)$ & $(1.6)$ \\
& 593 & 1,152 \\
& $(2.0)$ & $(0.9)$ \\
& 2,043 & -158 \\
& $(6.7)$ & -641 \\
\end{tabular}

Source: Table 9.A.13.

Notes: t-Statistics are in parentheses. Canada is excluded from export destinations. Equations include, as independent variables, GDP, GDPC, and net sales as the measure of affiliate production. 
Table 9.8

Coefficients for U.S. Majority-Owned Affiliates' Local and Export Sales and Minority-Owned Affiliates' Sales in Non-U.S. Export Equations, 1982

\begin{tabular}{lcccc}
\hline & \multicolumn{2}{c}{$\begin{array}{c}\text { Majority-Owned } \\
\text { Affiliates }\end{array}$} & & $\begin{array}{c}\text { Minority-Owned } \\
\text { Affiliates }\end{array}$ \\
\cline { 2 - 3 } & Net Local & Net Export & \\
\cline { 2 - 3 } Industry Group & Sales & Sales & Net Sales \\
\hline Chemicals & -270 & 1,141 & -2.616 \\
Nonelectrical machinery & $(.8)$ & $(3.0)$ & $(5.0)$ \\
Electrical machinery & $-1,665$ & 2,355 & 1.304 \\
Transport equipment & $(2.7)$ & $(4.8)$ & $(1.3)$ \\
& 1,212 & 3,408 & -1 \\
& $(1.4)$ & $(2.7)$ & $(.0)$ \\
& 586 & 15 & $-1,025$ \\
& $(7.0)$ & $(.2)$ & $(15.0)$ \\
\hline
\end{tabular}

Source: Table 9.A.13

Notes: t-Statistics are in parentheses. Canada is excluded from export destinations. Equations include, as independent variables, GDP, GDPC, and measures of affiliate production.

There is a preponderance of positive coefficients for minority-owned U.S. affiliate production in U.S. export equations and of negative coefficients in equations for exports by others to a market. This suggests that minority-owned production, even more than production by majorityowned affiliates, is a way in which U.S firms buy entry into a market or market share for themselves and hinder it for their foreign rivals.

\subsection{Conclusions}

The predominant relationship between production in a country by affiliates of Swedish and U.S. firms and exports to that country from Sweden and the United States is something between neutrality and complementarity. By the former we mean no effect on home country exports at all, and by the latter we mean inducing a higher level of home country exports.

The higher the level of Swedish affiliate production in a country, the higher the level of Swedish exports to that country in that industry. This relationship in OLS equations is confirmed in a 2SLS analysis that attempts to remove the effects of simultaneous determination of Swedish exports and host country affiliate production by Swedish firms and is observed whether production is measured by affiliate net sales or by net local sales. The same conclusions are produced by an analysis of changes over time in Swedish exports. Both high initial levels of Swedish 
affiliate production in a country and increases in production are positively associated with increases in Swedish exports to the country.

The results for the United States are more mixed. At the most disaggregated industry level, there is a predominance of positive relationships between affiliate net sales and U.S. exports, but there are a few negative coefficients, implying substitution of U.S. affiliate production for exports from the United States. Part of the positive influence of affiliate production on exports from the United States is the effect of affiliate production for exports from the host country, the effects of which are overwhelmingly positive. That is what we expect, because any substitution would take place outside the host country. Production by minority-owned affiliates of U.S. firms was somewhat more likely to be a means of buying market shares for the United States and denying them to others than was production by majority-owned affiliates. Furthermore, inclusion of production by minority-owned affiliates in the U.S. export equations increased the evidence for complementarity between U.S. exports and production by majority-owned U.S. affiliates.

\section{Appendix}

\section{Data}

The U.S. affiliate production data are from the individual firm reports underlying U.S. Department of Commerce (1985), a presumably quite complete census of U.S. direct investment abroad in 1982. Since these reports are confidential, the calculations described here were carried out for us within the Bureau of Economic Analysis of the U.S. Department of Commerce. We have omitted Canada from the U.S. equations for fear that it would be an outlier and unduly influence the results, and we omitted Malaysia, Mexico, the Philippines, Taiwan, and Thailand from the detailed industry equations, because some of the observations for net sales were negative. The reason apparently was that some respondents in these countries reported exports to the United States under items 806.30 and 807.00 of the U.S. Tariff Schedules at value added in the host country, rather than at the total value of the exports.

The Swedish data for production of individual foreign affiliates come from the Industriens Utredningsinstitut (IUI) of Stockholm. The IUI has completed four surveys of Swedish multinationals' foreign investment abroad covering 1965, 1970, 1974, and 1978. These surveys cover 
virtually all Swedish firms investing abroad and are in general comparable to the BEA surveys (see Swedenborg 1979, 1982).

Exports by the United States and all market economies to different countries, by the industry classifications used in the U.S. direct investment survey, were taken from United Nations trade tapes and converted from the SITC to this industry classification. Swedish exports by industry are from Statistiska Centralbyrån (Utdrag ur Makrobasen).

\begin{tabular}{|c|c|c|c|c|c|c|}
\hline \multirow[b]{2}{*}{ Industry (No. Obs.) } & \multirow[b]{2}{*}{ Intercept } & \multicolumn{4}{|c|}{ Coefficients of } & \multirow[b]{2}{*}{$\bar{R}^{2}$} \\
\hline & & GDP & $\begin{array}{c}\text { GDP per } \\
\text { Capita } \\
\text { (GDPC) }\end{array}$ & $\begin{array}{c}\text { Nordic } \\
\text { Country } \\
\text { (NORDIC) }\end{array}$ & $\begin{array}{l}\text { Net } \\
\text { Sales } \\
\text { (NS) }\end{array}$ & \\
\hline Paper products (66) & $\begin{array}{l}997 \\
(.16)\end{array}$ & $\begin{array}{l}-.02 \\
(1.82)\end{array}$ & $\begin{array}{c}1.72 \\
(1.28)\end{array}$ & $\begin{array}{c}225 \\
(11.3)\end{array}$ & $\begin{array}{c}.229 \\
(4.98)\end{array}$ & .81 \\
\hline Chemicals (66) & $\begin{array}{r}-30,912 \\
\quad(1.03)\end{array}$ & $\begin{array}{l}-.03 \\
(.41)\end{array}$ & $\begin{array}{l}14.89 \\
(2.30)\end{array}$ & $\begin{array}{l}1,032 \\
(10.7)\end{array}$ & $\begin{array}{c}.836 \\
(4.05)\end{array}$ & .78 \\
\hline $\begin{array}{l}\text { Metal manufacturing } \\
\text { (66) }\end{array}$ & $\begin{array}{r}-21,199 \\
(1.26)\end{array}$ & $\begin{array}{l}-.01 \\
(.27)\end{array}$ & $\begin{array}{l}9.86 \\
(2.62)\end{array}$ & $\begin{array}{l}459 \\
(8.5)\end{array}$ & $\begin{array}{c}.379 \\
(4.43)\end{array}$ & .75 \\
\hline $\begin{array}{l}\text { Nonelectrical } \\
\text { machinery (66) }\end{array}$ & $\begin{array}{r}-15,989 \\
(.68)\end{array}$ & $\begin{array}{c}.23 \\
(4.22)\end{array}$ & $\begin{array}{l}17.62 \\
(3.40)\end{array}$ & $\begin{array}{r}849 \\
(11.5)\end{array}$ & $\begin{array}{l}.359 \\
(12.9)\end{array}$ & .92 \\
\hline $\begin{array}{l}\text { Electrical machinery } \\
\text { (66) }\end{array}$ & $\begin{array}{r}-16,629 \\
(.91)\end{array}$ & $\begin{array}{l}.00 \\
(.11)\end{array}$ & $\begin{array}{l}20.54 \\
(5.29)\end{array}$ & $\begin{array}{l}500 \\
(8.6)\end{array}$ & $\begin{array}{c}.086 \\
(1.40)\end{array}$ & .72 \\
\hline $\begin{array}{l}\text { Transport equipment } \\
\text { (66) }\end{array}$ & $\begin{array}{r}-43,300 \\
(.97)\end{array}$ & $\begin{array}{r}.69 \\
(7.60)\end{array}$ & $\begin{array}{l}20.08 \\
(2.06)\end{array}$ & $\begin{array}{l}1,010 \\
(7.1)\end{array}$ & $\begin{array}{c}.312 \\
(3.49)\end{array}$ & .73 \\
\hline $\begin{array}{l}\text { Other manufacturing } \\
\text { (66) }\end{array}$ & $\begin{array}{r}-44,522 \\
(1.07)\end{array}$ & $\begin{array}{l}.04 \\
(.43)\end{array}$ & $\begin{array}{l}24.77 \\
(2.79)\end{array}$ & $\begin{array}{l}764 \\
(5.9)\end{array}$ & $\begin{array}{l}1.137 \\
(6.64)\end{array}$ & .68 \\
\hline
\end{tabular}

Notes: Dependent variable is Swedish exports to a country by an industry (thousand kronor). GDP = real GDP in 1978 in millions of international dollars, derived from data for 1980 in United Nations and Commission of the European Communities 1986 and extrapolated to 1978 and to countries not covered in the survey by methods described in Kravis and Lipsey 1984; GDPC = real GDP per capita in 1978 international dollars; NORDIC = dummy variable for membership in Nordic group (million kronor); and NS = affiliate net sales, derived as total affiliate sales minus imports from Sweden (thousand kronor). Numbers in parentheses are t-statistics. 
Table 9.A.2 2SLS Regression Results for Swedish Exports, 1978 (7 industry groups)

\begin{tabular}{|c|c|c|c|c|c|c|c|}
\hline \multirow[b]{2}{*}{ Industry (No. Obs.) } & \multirow[b]{2}{*}{ Intercept } & \multicolumn{5}{|c|}{ Coefficients of } & \multirow[b]{2}{*}{$\bar{R}^{2}$} \\
\hline & & GDP & $\begin{array}{c}\text { GDP per } \\
\text { Capita } \\
\text { (GDPC) }\end{array}$ & $\begin{array}{c}\text { Nordic } \\
\text { Country } \\
\text { (NORDIC) }\end{array}$ & $\begin{array}{c}\text { EEC } \\
\text { Member } \\
\text { (EEC) }\end{array}$ & $\begin{array}{l}\text { Net } \\
\text { Sales } \\
\text { (NS) }\end{array}$ & \\
\hline \multicolumn{8}{|c|}{ First Stage (Dependent Variable $=$ Net Sales) } \\
\hline Paper products (66) & $\begin{array}{r}-16,422 \\
\quad(1.11)\end{array}$ & $\begin{array}{c}.13 \\
(4.55)\end{array}$ & $\begin{array}{c}3.68 \\
(1.10)\end{array}$ & $\begin{array}{c}119 \\
(2.57)\end{array}$ & $\begin{array}{c}138 \\
(4.50)\end{array}$ & - & .56 \\
\hline Chemicals (66) & $\begin{array}{r}-4,767 \\
(.27)\end{array}$ & $\begin{array}{c}.18 \\
(5.22)\end{array}$ & $\begin{array}{l}3.96 \\
(1.01)\end{array}$ & $\begin{array}{c}93 \\
(1.71)\end{array}$ & $\begin{array}{c}106 \\
(2.93)\end{array}$ & - & .49 \\
\hline $\begin{array}{l}\text { Metal manufacturing } \\
(66)\end{array}$ & $\begin{array}{r}-4,723 \\
(.28)\end{array}$ & $\begin{array}{c}.22 \\
(6.48)\end{array}$ & $\begin{array}{l}2.80 \\
(.74)\end{array}$ & $\begin{array}{c}140 \\
(2.68)\end{array}$ & $\begin{array}{c}309 \\
(8.93)\end{array}$ & - & .76 \\
\hline $\begin{array}{l}\text { Nonelectrical } \\
\text { machinery }(66)\end{array}$ & $\begin{array}{r}-72,056 \\
(.91)\end{array}$ & $\begin{array}{c}.97 \\
(6.10)\end{array}$ & $\begin{array}{l}12.01 \\
(.67)\end{array}$ & $\begin{array}{r}-120 \\
(.48)\end{array}$ & $\begin{array}{l}1,201 \\
(7.29)\end{array}$ & - & .68 \\
\hline $\begin{array}{l}\text { Electrical machinery } \\
\quad(66)\end{array}$ & $\begin{array}{r}19,358 \\
(.51)\end{array}$ & $\begin{array}{c}.19 \\
(2.56)\end{array}$ & $\begin{array}{l}6.26 \\
(.73)\end{array}$ & $\begin{array}{c}32 \\
(.27)\end{array}$ & $\begin{array}{c}115 \\
(1.46)\end{array}$ & - & .17 \\
\hline $\begin{array}{l}\text { Transport equipment } \\
\text { (66) }\end{array}$ & $\begin{array}{r}-6,631 \\
(.11)\end{array}$ & $\begin{array}{r}-.10 \\
(.84)\end{array}$ & $\begin{array}{l}15.21 \\
(1.12)\end{array}$ & $\begin{array}{l}-254 \\
(1.35)\end{array}$ & $\begin{array}{c}384 \\
(3.08)\end{array}$ & 一 & .16 \\
\hline $\begin{array}{l}\text { Other manufacturing } \\
\text { (66) }\end{array}$ & $\begin{array}{r}-14,096 \\
(.51)\end{array}$ & $\begin{array}{c}.08 \\
(1.36)\end{array}$ & $\begin{array}{l}2.97 \\
(.47)\end{array}$ & $\begin{array}{l}-5 \\
(.06)\end{array}$ & $\begin{array}{c}225 \\
(3.91)\end{array}$ & - & .26 \\
\hline \multicolumn{8}{|l|}{ Second Stage } \\
\hline Paper products (66) & $\begin{array}{l}6,172 \\
(.82)\end{array}$ & $\begin{array}{l}-.05 \\
(2.61)\end{array}$ & $\begin{aligned}-.26 \\
(.14)\end{aligned}$ & $\begin{array}{l}201 \\
(7.9)\end{array}$ & - & $\begin{array}{c}.435 \\
(4.09)\end{array}$ & .75 \\
\hline Chemicals (66) & $\begin{array}{c}-122 \\
(.00)\end{array}$ & $\begin{array}{l}-.51 \\
(2.17)\end{array}$ & $\begin{array}{r}-7.98 \\
\quad(.51)\end{array}$ & $\begin{array}{l}783 \\
(3.7)\end{array}$ & - & $\begin{array}{l}3.511 \\
(3.09)\end{array}$ & .50 \\
\hline $\begin{array}{l}\text { Metal manufacturing } \\
(66)\end{array}$ & $\begin{array}{r}-18,247 \\
(1.06)\end{array}$ & $\begin{array}{r}-.04 \\
(.85)\end{array}$ & $\begin{array}{l}7.90 \\
(1.97)\end{array}$ & $\begin{array}{l}443 \\
(7.9)\end{array}$ & - & $\begin{array}{l}.500 \\
(4.34)\end{array}$ & .75 \\
\hline $\begin{array}{l}\text { Nonelectrical } \\
\text { machinery (66) }\end{array}$ & $\begin{array}{r}-14,603 \\
(.61)\end{array}$ & $\begin{array}{c}.22 \\
(3.60)\end{array}$ & $\begin{array}{l}17.02 \\
(3.08)\end{array}$ & $\begin{array}{c}850 \\
(11.5)\end{array}$ & - & $\begin{array}{l}.368 \\
(9.05)\end{array}$ & .91 \\
\hline $\begin{array}{l}\text { Electrical machinery } \\
\quad(66)\end{array}$ & $\begin{array}{r}-21,828 \\
(.87)\end{array}$ & $\begin{array}{l}-.08 \\
(.78)\end{array}$ & $\begin{array}{l}15.73 \\
(2.19)\end{array}$ & $\begin{array}{l}487 \\
(6.2)\end{array}$ & - & $\begin{array}{l}.516 \\
(1.15)\end{array}$ & .60 \\
\hline $\begin{array}{l}\text { Transport equipment } \\
\text { (66) }\end{array}$ & $\begin{array}{r}-24,446 \\
(.41)\end{array}$ & $\begin{array}{c}.76 \\
(6.06)\end{array}$ & $\begin{array}{l}.75 \\
(.05)\end{array}$ & $\begin{array}{l}1,165 \\
(5.7)\end{array}$ & - & $\begin{array}{c}.921 \\
(2.85)\end{array}$ & .60 \\
\hline $\begin{array}{l}\text { Other manufacturing } \\
\text { (66) }\end{array}$ & $\begin{array}{r}-6,108 \\
(.10)\end{array}$ & $\begin{array}{r}-.06 \\
(.47)\end{array}$ & $\begin{array}{l}7.60 \\
(.54)\end{array}$ & $\begin{array}{l}772 \\
(4.2)\end{array}$ & - & $\begin{array}{l}2.490 \\
(4.58)\end{array}$ & .50 \\
\hline
\end{tabular}

Notes: EEC member = dummy variable for membership in European Economic Community. See table 9.A.1. 
Table 9.A.3 Comparison of OLS Regression Results for Swedish Exports Based on Net Sales and Net Local Sales, 1978 (5 industry groups)

\begin{tabular}{|c|c|c|c|c|c|c|c|}
\hline \multirow[b]{2}{*}{ Industry (No. Obs.) } & \multirow[b]{2}{*}{ Intercept } & \multicolumn{5}{|c|}{ Coefficients of } & \multirow[b]{2}{*}{$\bar{R}^{2}$} \\
\hline & & GDP & $\begin{array}{l}\text { GDP per } \\
\text { Capita } \\
\text { (GDPC) }\end{array}$ & $\begin{array}{c}\text { Nordic } \\
\text { Country } \\
\text { (NORDIC) }\end{array}$ & $\begin{array}{l}\text { Net } \\
\text { Sales } \\
\text { (NS) }\end{array}$ & $\begin{array}{c}\text { Net } \\
\text { Local } \\
\text { Sales } \\
\text { (NLS) }\end{array}$ & \\
\hline Paper products (19) & $\begin{array}{r}-25,102 \\
(.56)\end{array}$ & $\begin{array}{l}-.03 \\
(1.16)^{\mathrm{a}}\end{array}$ & $\begin{array}{l}5.83 \\
(.87)\end{array}$ & $\begin{array}{c}217 \\
(5.20)\end{array}$ & $\begin{array}{c}.217 \\
(2.11)\end{array}$ & - & .74 \\
\hline Chemicals (30) & $\begin{array}{r}-92,998 \\
(1.10)\end{array}$ & $\begin{array}{c}-.07 \\
(.61)\end{array}$ & $\begin{array}{l}27.62 \\
(1.91)\end{array}$ & $\begin{array}{c}984 \\
(6.52)\end{array}$ & $\begin{array}{c}.809 \\
(2.29)\end{array}$ & - & .74 \\
\hline $\begin{array}{l}\text { Metal manufacturing } \\
\text { (19) }\end{array}$ & $\begin{array}{r}-112,624 \\
(1.01)\end{array}$ & $\begin{array}{c}-.03 \\
(.35)\end{array}$ & $\begin{array}{l}25.15 \\
(1.52)\end{array}$ & $\begin{array}{c}424 \\
(3.68)\end{array}$ & $\begin{array}{l}.330 \\
(1.59)\end{array}$ & - & .60 \\
\hline $\begin{array}{l}\text { Nonelectrical } \\
\text { machinery (21) }\end{array}$ & $\begin{array}{r}-64,951 \\
(.57)\end{array}$ & $\begin{array}{c}.21 \\
(2.00)\end{array}$ & $\begin{array}{l}29.79 \\
(1.82)\end{array}$ & $\begin{array}{c}794 \\
(5.49)\end{array}$ & $\begin{array}{c}.336 \\
(5.87)\end{array}$ & - & .85 \\
\hline $\begin{array}{l}\text { Electrical machinery } \\
\text { (24) }\end{array}$ & $\begin{array}{r}-14,801 \\
(.27)\end{array}$ & $\begin{array}{c}.01 \\
(.24)\end{array}$ & $\begin{array}{l}19.98 \\
(2.39)\end{array}$ & $\begin{array}{c}504 \\
(7.54)\end{array}$ & $\begin{array}{l}.083 \\
(1.11)\end{array}$ & - & .80 \\
\hline Paper products (19) & $\begin{array}{r}-20,370 \\
(.50)\end{array}$ & $\begin{array}{l}-.05 \\
(1.79)\end{array}$ & $\begin{array}{l}5.15 \\
(.85)\end{array}$ & $\begin{array}{c}209 \\
(5.43)\end{array}$ & - & $\begin{array}{l}.351 \\
(2.79)\end{array}$ & .76 \\
\hline Chemicals (30) & $\begin{array}{r}-98,567 \\
(1.16)\end{array}$ & $\begin{array}{l}-.09 \\
(.73)\end{array}$ & $\begin{array}{l}29.42 \\
(2.06)\end{array}$ & $\begin{array}{c}995 \\
(6.64)\end{array}$ & - & $\begin{array}{c}.870 \\
(2.32)\end{array}$ & .73 \\
\hline $\begin{array}{l}\text { Metal manufacturing } \\
\text { (19) }\end{array}$ & $\begin{array}{r}-109,646 \\
(.93)\end{array}$ & $\begin{array}{c}.02 \\
(.22)\end{array}$ & $\begin{array}{l}30.34 \\
(1.77)\end{array}$ & $\begin{array}{c}400 \\
(3.18)\end{array}$ & - & $\begin{array}{l}.268 \\
(.80)\end{array}$ & .52 \\
\hline $\begin{array}{l}\text { Nonelectrical } \\
\text { machinery (21) }\end{array}$ & $\begin{array}{r}-56,852 \\
(.52)\end{array}$ & $\begin{array}{c}.09 \\
(.83)\end{array}$ & $\begin{array}{l}33.00 \\
(2.15)\end{array}$ & $\begin{array}{c}787 \\
(5.74)\end{array}$ & - & $\begin{array}{l}.508 \\
(6.32)\end{array}$ & .86 \\
\hline $\begin{array}{l}\text { Electrical machinery } \\
\text { (24) }\end{array}$ & $\begin{array}{r}-15,333 \\
(.28)\end{array}$ & $\begin{array}{l}.01 \\
(.25)\end{array}$ & $\begin{array}{l}20.19 \\
(2.42)\end{array}$ & $\begin{array}{c}505 \\
(7.55)\end{array}$ & - & $\begin{array}{l}.085 \\
(1.12)\end{array}$ & .79 \\
\hline
\end{tabular}

Notes: Net local sales in thousands of kronor. See table 9.A.1. 
Table 9.A.4

OLS Regression Results for Changes in Swedish Exports, 1970-78 (7 industry groups)

\begin{tabular}{|c|c|c|c|c|c|c|}
\hline \multirow[b]{2}{*}{ Industry (No. Obs.) } & \multirow[b]{2}{*}{ Intercept } & \multicolumn{4}{|c|}{ Coefficients of } & \multirow[b]{2}{*}{$\bar{R}^{2}$} \\
\hline & & $\begin{array}{c}\text { Change in } \\
\text { GDP } \\
(\Delta G D P)\end{array}$ & $\begin{array}{c}\text { Exports } \\
1970 \\
\text { (EXP70) }\end{array}$ & $\begin{array}{c}\text { Change in } \\
\text { Net Sales } \\
(\Delta N S)\end{array}$ & $\begin{array}{c}\text { Net } \\
\text { Sales } \\
\text { (NS70) }\end{array}$ & \\
\hline Paper products (66) & $\begin{array}{l}-.53 \\
(.02)\end{array}$ & $\begin{aligned}-.04 \\
(.98)\end{aligned}$ & $\begin{array}{c}2.44 \\
(14.1)\end{array}$ & $\begin{array}{l}.058 \\
(1.62)\end{array}$ & - & .83 \\
\hline Chemicals (66) & $\begin{array}{r}-1,280 \\
(.14)\end{array}$ & $\begin{array}{l}-.10 \\
(.88)\end{array}$ & $\begin{array}{c}2.68 \\
(25.1)\end{array}$ & $\begin{array}{l}.179 \\
(1.60)\end{array}$ & - & .93 \\
\hline $\begin{array}{l}\text { Metal manufacturing } \\
(66)\end{array}$ & $\begin{array}{l}469 \\
(.11)\end{array}$ & $\begin{array}{l}.05 \\
(.85)\end{array}$ & $\begin{array}{c}2.27 \\
(25.3)\end{array}$ & $\begin{array}{l}-.158 \\
(3.19)\end{array}$ & - & .94 \\
\hline $\begin{array}{l}\text { Nonelectrical } \\
\text { machinery (66) }\end{array}$ & $\begin{array}{r}-7,683 \\
(.73)\end{array}$ & $\begin{array}{c}.36 \\
(2.96)\end{array}$ & $\begin{array}{c}1.54 \\
(14.6)\end{array}$ & $\begin{array}{c}.062 \\
(1.81)\end{array}$ & - & .93 \\
\hline $\begin{array}{l}\text { Electrical machinery } \\
\text { (66) }\end{array}$ & $\begin{array}{r}24,239 \\
(1.64)\end{array}$ & $\begin{array}{l}-.02 \\
(.12)\end{array}$ & $\begin{array}{l}2.03 \\
(7.5)\end{array}$ & $\begin{array}{l}-.132 \\
(1.46)\end{array}$ & - & .46 \\
\hline $\begin{array}{l}\text { Transport equipment } \\
\text { (66) }\end{array}$ & $\begin{array}{r}15,199 \\
(.60)\end{array}$ & $\begin{array}{l}1.14 \\
(4.0)\end{array}$ & $\begin{array}{c}.84 \\
(6.2)\end{array}$ & $\begin{array}{l}.276 \\
(3.64)\end{array}$ & - & .61 \\
\hline $\begin{array}{l}\text { Other manufacturing } \\
\text { (66) }\end{array}$ & $\begin{array}{r}16,233 \\
(1.40)\end{array}$ & $\begin{array}{l}-.21 \\
(1.64)\end{array}$ & $\begin{array}{c}1.68 \\
(17.3)\end{array}$ & $\begin{array}{c}.444 \\
(4.65)\end{array}$ & - & .89 \\
\hline Paper products $(66)$ & $\begin{array}{c}-849 \\
(.28)\end{array}$ & $\begin{array}{l}-.01 \\
(.33)\end{array}$ & $\begin{array}{c}2.49 \\
(15.2)\end{array}$ & - & $\begin{array}{c}.201 \\
(1.36)\end{array}$ & .83 \\
\hline Chemicals (66) & $\begin{array}{r}-3,334 \\
(.38)\end{array}$ & $\begin{aligned}-.08 \\
(.83)\end{aligned}$ & $\begin{array}{c}2.67 \\
(26.7)\end{array}$ & - & $\begin{array}{c}.448 \\
(2.34)\end{array}$ & .93 \\
\hline $\begin{array}{l}\text { Metal manufacturing } \\
(66)\end{array}$ & $\begin{array}{l}214 \\
(.05)\end{array}$ & $\begin{array}{l}-.01 \\
(.18)\end{array}$ & $\begin{array}{c}2.27 \\
(22.5)\end{array}$ & - & $\begin{array}{l}-.271 \\
(2.60)\end{array}$ & .93 \\
\hline $\begin{array}{l}\text { Nonelectrical } \\
\text { machinery (66) }\end{array}$ & $\begin{array}{r}-6,759 \\
(.65)\end{array}$ & $\begin{array}{c}.31 \\
(2.45)\end{array}$ & $\begin{array}{l}1.56 \\
(17.5)\end{array}$ & 一 & $\begin{array}{l}.122 \\
(2.27)\end{array}$ & .93 \\
\hline $\begin{array}{l}\text { Electrical machinery } \\
\quad(66)\end{array}$ & $\begin{array}{r}21,589 \\
(1.44)\end{array}$ & $\begin{array}{l}-.15 \\
(.94)\end{array}$ & $\begin{array}{l}1.78 \\
(6.2)\end{array}$ & - & $\begin{array}{c}.282 \\
(1.04)\end{array}$ & .47 \\
\hline $\begin{array}{l}\text { Transport equipment } \\
\text { (66) }\end{array}$ & $\begin{array}{r}18,450 \\
(.70)\end{array}$ & $\begin{array}{l}1.08 \\
(3.59)\end{array}$ & $\begin{array}{c}.87 \\
(6.1)\end{array}$ & - & $\begin{array}{l}1.899 \\
(2.71)\end{array}$ & .57 \\
\hline $\begin{array}{l}\text { Other manufacturing } \\
\text { (66) }\end{array}$ & $\begin{array}{r}11,328 \\
(.88)\end{array}$ & $\begin{array}{l}-.12 \\
(.88)\end{array}$ & $\begin{array}{c}1.71 \\
(14.3)\end{array}$ & - & $\begin{array}{c}.836 \\
(2.44)\end{array}$ & .86 \\
\hline
\end{tabular}

Note: Dependent variable is change in Swedish exports to a country by an industry (thousand kronor). For definitions of variables, see text. 
Table 9.A.5

OLS Equations for U.S. Exports Based on Net Sales by MajorityOwned U.S. Affiliates, 1982 (30 industries)

\begin{tabular}{|c|c|c|c|c|c|c|}
\hline \multirow[b]{2}{*}{$\begin{array}{l}\text { Industry } \\
\text { No. }\end{array}$} & \multirow[b]{2}{*}{$\begin{array}{l}\text { Intercept } \\
\text { (\$ millions) }\end{array}$} & \multicolumn{3}{|c|}{ Coefficients of } & \multirow[b]{2}{*}{$\bar{R}^{2}$} & \multirow[b]{2}{*}{$\begin{array}{l}\text { No. of } \\
\text { Obs. }\end{array}$} \\
\hline & & GDP & $\begin{array}{c}\text { GDP per } \\
\text { Capita } \\
\text { (GDPC) }\end{array}$ & $\begin{array}{l}\text { Net } \\
\text { Sales } \\
\text { (NS) }\end{array}$ & & \\
\hline 1 & $\begin{array}{c}-4.0 \\
(0.3)\end{array}$ & $\begin{array}{l}.094 \\
(2.0)\end{array}$ & $\begin{array}{c}4.5 \\
(2.0)\end{array}$ & $\begin{array}{c}.01 \\
(0.5)\end{array}$ & .23 & 48 \\
\hline 2 & $\begin{array}{l}-.2 \\
(0.3)\end{array}$ & $\begin{array}{l}.015 \\
(4.0)\end{array}$ & $\begin{array}{c}.26 \\
(1.8)\end{array}$ & $\begin{array}{c}-.00 \\
(0.0)\end{array}$ & .51 & 47 \\
\hline 3 & $\begin{array}{c}.3 \\
(0.0)\end{array}$ & $\begin{array}{l}.027 \\
(1.2)\end{array}$ & $\begin{array}{l}1.86 \\
(1.5)\end{array}$ & $\begin{array}{c}-.04 \\
(1.4)\end{array}$ & .05 & 43 \\
\hline 4 & $\begin{array}{c}-3.7 \\
(0.1)\end{array}$ & $\begin{array}{c}1.40 \\
(10.4)\end{array}$ & $\begin{array}{l}3.01 \\
(0.4)\end{array}$ & $\begin{array}{c}-.23 \\
(3.7)\end{array}$ & .72 & 48 \\
\hline 5 & $\begin{array}{c}2.2 \\
(0.2)\end{array}$ & $\begin{array}{l}.142 \\
(4.4)\end{array}$ & $\begin{array}{l}4.29 \\
(2.5)\end{array}$ & $\begin{array}{c}.17 \\
(2.4)\end{array}$ & .58 & 48 \\
\hline 6 & & & NA & & & \\
\hline 7 & & & NA & & & \\
\hline 8 & $\begin{array}{c}3.1 \\
(0.7)\end{array}$ & $\begin{array}{c}.04 \\
(2.5)\end{array}$ & $\begin{array}{c}.83 \\
(1.1)\end{array}$ & $\begin{array}{c}-.01 \\
(0.3)\end{array}$ & .17 & 48 \\
\hline 9 & $\begin{array}{c}2.1 \\
(0.6)\end{array}$ & $\begin{array}{l}.028 \\
(2.2)\end{array}$ & $\begin{array}{l}.58 \\
(0.9)\end{array}$ & $\begin{array}{c}.30 \\
(9.9)\end{array}$ & .79 & 48 \\
\hline 10 & $\begin{array}{r}-11.7 \\
(1.6)\end{array}$ & $\begin{array}{c}.44 \\
(13.9)\end{array}$ & $\begin{array}{c}1.6 \\
(1.3)\end{array}$ & $\begin{array}{r}-.083 \\
(4.7)\end{array}$ & .86 & 48 \\
\hline 11 & $\begin{array}{l}-.6 \\
(0.3)\end{array}$ & $\begin{array}{l}.020 \\
(1.8)\end{array}$ & $\begin{array}{c}1.0 \\
(2.4)\end{array}$ & $\begin{array}{l}.010 \\
(1.3)\end{array}$ & .43 & 48 \\
\hline 12 & $\begin{array}{l}15.5 \\
(3.8)\end{array}$ & $\begin{array}{l}.071 \\
(5.3)\end{array}$ & $\begin{array}{r}-1.13 \\
(1.6)\end{array}$ & $\begin{array}{c}.27 \\
(4.5)\end{array}$ & .61 & 47 \\
\hline 13 & $\begin{array}{l}16.0 \\
(0.5)\end{array}$ & $\begin{array}{c}1.52 \\
(12.1)\end{array}$ & $\begin{array}{l}2.51 \\
(0.4)\end{array}$ & $\begin{array}{c}-.01 \\
(0.2)\end{array}$ & .81 & 48 \\
\hline 14 & $\begin{array}{c}4.4 \\
(0.5)\end{array}$ & $\begin{array}{c}.31 \\
(10.5)\end{array}$ & $\begin{array}{c}1.7 \\
(1.1)\end{array}$ & $\begin{array}{c}-.01 \\
(0.4)\end{array}$ & .77 & 48 \\
\hline 15 & $\begin{array}{l}2.0 \\
(0.5)\end{array}$ & $\begin{array}{l}.030 \\
(2.1)\end{array}$ & $\begin{array}{l}1.48 \\
(2.1)\end{array}$ & $\begin{array}{l}.029 \\
(1.8)\end{array}$ & .34 & 48 \\
\hline 16 & $\begin{array}{c}-2.0 \\
(0.7)\end{array}$ & $\begin{array}{l}.036 \\
(3.2)\end{array}$ & $\begin{array}{l}1.44 \\
(2.9)\end{array}$ & $\begin{array}{l}.038 \\
(1.5)\end{array}$ & .56 & 48 \\
\hline 17 & $\begin{array}{l}17.2 \\
(1.0)\end{array}$ & $\begin{array}{c}.04 \\
(0.6)\end{array}$ & $\begin{array}{l}3.30 \\
(1.1)\end{array}$ & $\begin{array}{c}-.04 \\
(0.1)\end{array}$ & -.01 & 48 \\
\hline 18 & $\begin{array}{r}-22.5 \\
(2.1)\end{array}$ & $\begin{array}{c}.538 \\
(13.6)\end{array}$ & $\begin{array}{c}3.4 \\
(1.8)\end{array}$ & $\begin{array}{c}-.33 \\
(3.3)\end{array}$ & .85 & 48 \\
\hline 19 & $\begin{array}{c}2.2 \\
(0.1)\end{array}$ & $\begin{array}{l}.177 \\
(1.9)\end{array}$ & $\begin{array}{l}8.15 \\
(1.8)\end{array}$ & $\begin{array}{c}.02 \\
(0.4)\end{array}$ & .20 & 48 \\
\hline 20 & & & NA & & & \\
\hline 21 & $\begin{array}{l}35.1 \\
(1.2)\end{array}$ & $\begin{array}{l}.036 \\
(0.3)\end{array}$ & $\begin{array}{c}6.8 \\
(1.4)\end{array}$ & $\begin{array}{l}.077 \\
(1.0)\end{array}$ & .07 & 48 \\
\hline 22 & $\begin{array}{r}-18.5 \\
(0.5)\end{array}$ & $\begin{array}{l}.115 \\
(0.7)\end{array}$ & $\begin{array}{l}16.8 \\
(2.9)\end{array}$ & $\begin{array}{l}.283 \\
(7.5)\end{array}$ & .83 & 48 \\
\hline
\end{tabular}


Table 9.A.5 (continued)

\begin{tabular}{|c|c|c|c|c|c|c|}
\hline \multirow[b]{2}{*}{$\begin{array}{l}\text { Industry } \\
\text { No. }\end{array}$} & \multirow[b]{2}{*}{$\begin{array}{l}\text { Intercept } \\
\text { (\$ millions) }\end{array}$} & \multicolumn{3}{|c|}{ Coefficients of } & \multirow[b]{2}{*}{$\bar{R}^{2}$} & \multirow[b]{2}{*}{$\begin{array}{l}\text { No. of } \\
\text { Obs. }\end{array}$} \\
\hline & & GDP & $\begin{array}{c}\text { GDP per } \\
\text { Capita } \\
\text { (GDPC) }\end{array}$ & $\begin{array}{l}\text { Net } \\
\text { Sales } \\
\text { (NS) }\end{array}$ & & \\
\hline 23 & $\begin{array}{l}26.4 \\
(0.4)\end{array}$ & $\begin{array}{l}.694 \\
(3.1)\end{array}$ & $\begin{array}{l}22.6 \\
(2.1)\end{array}$ & $\begin{array}{l}.171 \\
(1.4)\end{array}$ & .46 & 48 \\
\hline 24 & $\begin{array}{c}-2.7 \\
(0.4)\end{array}$ & $\begin{array}{c}.01 \\
(0.3)\end{array}$ & $\begin{array}{l}2.50 \\
(2.3)\end{array}$ & $\begin{array}{l}.026 \\
(0.4)\end{array}$ & .10 & 48 \\
\hline 25 & $\begin{array}{c}5.6 \\
(0.4)\end{array}$ & $\begin{array}{c}.25 \\
(5.7)\end{array}$ & $\begin{array}{l}2.5 \\
(1.1)\end{array}$ & $\begin{array}{r}-.002 \\
(0.1)\end{array}$ & .52 & 48 \\
\hline 26 & $\begin{array}{c}9.8 \\
(0.6)\end{array}$ & $\begin{array}{l}.146 \\
(2.1)\end{array}$ & $\begin{array}{c}-.08 \\
(0.0)\end{array}$ & $\begin{array}{c}.49 \\
(7.5)\end{array}$ & .76 & 48 \\
\hline 27 & $\begin{array}{c}-21.1 \\
(0.7)\end{array}$ & $\begin{array}{l}.579 \\
(5.2)\end{array}$ & $\begin{array}{l}14.7 \\
(2.7)\end{array}$ & $\begin{array}{c}.06 \\
(0.4)\end{array}$ & .59 & 48 \\
\hline 28 & $\begin{array}{c}-3.9 \\
(0.1)\end{array}$ & $\begin{array}{l}.002 \\
(0.0)\end{array}$ & $\begin{array}{l}19.6 \\
(2.2)\end{array}$ & $\begin{array}{l}.012 \\
(0.7)\end{array}$ & .09 & 48 \\
\hline 29 & & & NA & & & \\
\hline 30 & $\begin{array}{r}-39.3 \\
(1.3)\end{array}$ & $\begin{array}{c}1.27 \\
(11.4)\end{array}$ & $\begin{array}{r}-1.18 \\
(0.2)\end{array}$ & $\begin{array}{r}-3.84 \\
(5.8)\end{array}$ & .75 & 48 \\
\hline 31 & $\begin{array}{l}-.2 \\
(0.1)\end{array}$ & $\begin{array}{l}.030 \\
(2.5)\end{array}$ & $\begin{array}{l}1.17 \\
(2.1)\end{array}$ & $\begin{array}{l}.043 \\
(1.4)\end{array}$ & .38 & 48 \\
\hline 32 & $\begin{array}{c}-1.4 \\
(0.4)\end{array}$ & $\begin{array}{l}.033 \\
(2.8)\end{array}$ & $\begin{array}{l}1.46 \\
(2.7)\end{array}$ & $\begin{array}{r}-.007 \\
(0.2)\end{array}$ & .35 & 48 \\
\hline 33 & $\begin{array}{c}-39.6 \\
(2.2)\end{array}$ & $\begin{array}{c}.83 \\
(13.4)\end{array}$ & $\begin{array}{l}12.4 \\
(4.0)\end{array}$ & $\begin{array}{l}.162 \\
(7.1)\end{array}$ & .92 & 48 \\
\hline 34 & $\begin{array}{r}-15.8 \\
(1.1)\end{array}$ & $\begin{array}{l}.133 \\
(2.4)\end{array}$ & $\begin{array}{l}6.12 \\
(2.5)\end{array}$ & $\begin{array}{c}.34 \\
(2.3)\end{array}$ & .53 & 48 \\
\hline
\end{tabular}

Notes: Dependent variable is U.S. exports to a country by an industry (thou sand dollars). Canada, Malaysia, Mexico, Philippines, Taiwan, and Thailand are excluded from the equations. GDP = real GDP in 1982 in millions of international dollars, derived from data for 1980 in United Nations and Commission of the European Communities 1986, and extrapolated to 1982 and to countries not covered in the survey by methods described in Kravis and Lipsey 1984; GDPC = real GDP per capita in 1982; and Net Sales = affiliate net sales, derived as total affiliate sales minus imports from the United States (thousand dollars). Number in parentheses are t-statistics.

The 34 industries are the following: (1) grain mill and bakery products; (2) beverages; (3) tobacco; (4) other food products; (5) textiles and apparel; (6) leather and leatherware; (7) pulp and paper; (8) paper products; (9) printing and publishing; (10) drugs; (11) soap, cleansers, toilet goods; (12) agricultural chemicals; (13) industrial chemicals; (14) other chemicals; (15) rubber products; (16) plastic products; (17) primary metals, ferrous; (18) primary metals, nonferrous; (19) fabricated metals; (20) farm and garden machinery; (21) construction and related machinery; (22) office and computing machinery; (23) other non-electrical machinery; (24) household appliances; (25) radio, TV, and communication equipment; (26) electronic components; (27) other electrical machinery; (28) motor vehicles and equipment; (29) other transport equipment; (30) lumber, wood, furniture and fixtures; (31) glass products; (32) stone, clay, cement, and concrete; (33) instruments and related products; and (34) other industries. 
Table 9.A.6

OLS Equations for U.S. Exports Based on Net Local Sales by

Majority-Owned U.S. Affiliates, 1982 (30 industries)

\begin{tabular}{|c|c|c|c|c|c|c|}
\hline \multirow[b]{2}{*}{$\begin{array}{l}\text { Industry } \\
\text { No. }\end{array}$} & \multirow[b]{2}{*}{$\begin{array}{l}\text { Intercept } \\
\text { (\$ millions) }\end{array}$} & \multicolumn{3}{|c|}{ Coefficients of } & \multirow[b]{2}{*}{$\bar{R}^{2}$} & \multirow[b]{2}{*}{$\begin{array}{l}\text { No. of } \\
\text { Obs. }\end{array}$} \\
\hline & & GDP & $\begin{array}{l}\text { GDP per } \\
\text { Capita } \\
\text { (GDPC) }\end{array}$ & $\begin{array}{c}\text { Net } \\
\text { Local } \\
\text { Sales } \\
\text { (NLS) }\end{array}$ & & \\
\hline 1 & $\begin{array}{c}-4.0 \\
(0.3)\end{array}$ & $\begin{array}{l}.098 \\
(2.1)\end{array}$ & $\begin{array}{l}4.52 \\
(2.0)\end{array}$ & $\begin{array}{c}.01 \\
(0.3)\end{array}$ & .23 & 48 \\
\hline 2 & $\begin{array}{l}-.2 \\
(0.2)\end{array}$ & $\begin{array}{l}.015 \\
(3.9)\end{array}$ & $\begin{array}{c}.26 \\
(1.8)\end{array}$ & $\begin{array}{c}-.00 \\
(0.2)\end{array}$ & .51 & 47 \\
\hline 3 & $\begin{array}{c}.8 \\
(0.1)\end{array}$ & $\begin{array}{l}.026 \\
(1.1)\end{array}$ & $\begin{array}{l}1.67 \\
(1.3)\end{array}$ & $\begin{array}{c}-.04 \\
(1.1)\end{array}$ & .03 & 43 \\
\hline 4 & $\begin{array}{r}-1.7 \\
(0.0)\end{array}$ & $\begin{array}{c}1.44 \\
(11.0)\end{array}$ & $\begin{array}{l}1.97 \\
(0.3)\end{array}$ & $\begin{array}{c}-.31 \\
(4.3)\end{array}$ & .74 & 48 \\
\hline 5 & $\begin{array}{c}1.1 \\
(0.1)\end{array}$ & $\begin{array}{l}.105 \\
(3.2)\end{array}$ & $\begin{array}{l}4.83 \\
(3.1)\end{array}$ & $\begin{array}{c}.48 \\
(3.6)\end{array}$ & .63 & 48 \\
\hline 6 & & & NA & & & \\
\hline 7 & & & NA & & & \\
\hline 8 & $\begin{array}{c}3.1 \\
(0.7)\end{array}$ & $\begin{array}{l}.040 \\
(2.5)\end{array}$ & $\begin{array}{c}.82 \\
(1.1)\end{array}$ & $\begin{array}{c}-.01 \\
(0.3)\end{array}$ & .17 & 48 \\
\hline 9 & $\begin{array}{l}2.5 \\
(0.7)\end{array}$ & $\begin{array}{l}.029 \\
(2.3)\end{array}$ & $\begin{array}{c}.43 \\
(0.6)\end{array}$ & $\begin{array}{c}.40 \\
(9.8)\end{array}$ & .79 & 48 \\
\hline 10 & $\begin{array}{l}11.1 \\
(1.7)\end{array}$ & $\begin{array}{c}.514 \\
(14.7)\end{array}$ & $\begin{array}{l}1.06 \\
(1.0)\end{array}$ & $\begin{array}{r}-.162 \\
(6.2)\end{array}$ & .89 & 48 \\
\hline 11 & $\begin{array}{l}-.8 \\
(0.3)\end{array}$ & $\begin{array}{l}.018 \\
(1.6)\end{array}$ & $\begin{array}{l}1.06 \\
(2.5)\end{array}$ & $\begin{array}{l}.013 \\
(1.4)\end{array}$ & .43 & 48 \\
\hline 12 & $\begin{array}{l}14.9 \\
(3.4)\end{array}$ & $\begin{array}{l}.073 \\
(5.1)\end{array}$ & $\begin{array}{c}-.77 \\
(1.0)\end{array}$ & $\begin{array}{l}.300 \\
(3.7)\end{array}$ & .57 & 47 \\
\hline 13 & $\begin{array}{l}15.2 \\
(0.4)\end{array}$ & $\begin{array}{c}1.67 \\
(12.5)\end{array}$ & $\begin{array}{l}3.74 \\
(0.6)\end{array}$ & $\begin{array}{r}-.142 \\
(2.1)\end{array}$ & .83 & 48 \\
\hline 14 & $\begin{array}{c}4.5 \\
(0.5)\end{array}$ & $\begin{array}{c}.31 \\
(10.4)\end{array}$ & $\begin{array}{l}1.69 \\
(1.1)\end{array}$ & $\begin{array}{r}-.020 \\
(0.6)\end{array}$ & .77 & 48 \\
\hline 15 & $\begin{array}{l}1.6 \\
(0.4)\end{array}$ & $\begin{array}{l}.031 \\
(2.2)\end{array}$ & $\begin{array}{l}1.57 \\
(2.2)\end{array}$ & $\begin{array}{l}.033 \\
(1.8)\end{array}$ & .34 & 48 \\
\hline 16 & $\begin{array}{c}-2.2 \\
(0.8)\end{array}$ & $\begin{array}{l}.032 \\
(2.6)\end{array}$ & $\begin{array}{l}1.56 \\
(3.2)\end{array}$ & $\begin{array}{l}.059 \\
(1.6)\end{array}$ & .56 & 48 \\
\hline 17 & $\begin{array}{l}17.1 \\
(1.0)\end{array}$ & $\begin{array}{l}.035 \\
(0.5)\end{array}$ & $\begin{array}{l}3.26 \\
(1.1)\end{array}$ & $\begin{array}{l}.013 \\
(0.0)\end{array}$ & -.01 & 48 \\
\hline 18 & $\begin{array}{r}-21.4 \\
(2.1)\end{array}$ & $\begin{array}{c}.554 \\
(14.1)\end{array}$ & $\begin{array}{l}3.12 \\
(1.8)\end{array}$ & $\begin{array}{r}-.542 \\
(3.8)\end{array}$ & .86 & 48 \\
\hline 19 & $\begin{array}{c}2.1 \\
(0.1)\end{array}$ & $\begin{array}{l}.170 \\
(1.8)\end{array}$ & $\begin{array}{l}8.13 \\
(1.8)\end{array}$ & $\begin{array}{l}.031 \\
(0.5)\end{array}$ & .20 & 48 \\
\hline 20 & & & NA & & & \\
\hline 21 & $\begin{array}{l}32.2 \\
(1.1)\end{array}$ & $\begin{array}{l}.014 \\
(0.1)\end{array}$ & $\begin{array}{c}7.5 \\
(1.6)\end{array}$ & $\begin{array}{l}.180 \\
(1.5)\end{array}$ & .09 & 48 \\
\hline
\end{tabular}


Table 9.A.6 (continued)

\begin{tabular}{|c|c|c|c|c|c|c|}
\hline \multirow[b]{2}{*}{$\begin{array}{l}\text { Industry } \\
\text { No. }\end{array}$} & \multirow[b]{2}{*}{$\begin{array}{c}\text { Intercept } \\
\text { (\$ millions) }\end{array}$} & \multicolumn{3}{|c|}{ Coefficients of } & \multirow[b]{2}{*}{$\bar{R}^{2}$} & \multirow[b]{2}{*}{$\begin{array}{l}\text { No. of } \\
\text { Obs. }\end{array}$} \\
\hline & & GDP & $\begin{array}{l}\text { GDP per } \\
\text { Capita } \\
\text { (GDPC) }\end{array}$ & $\begin{array}{c}\text { Net } \\
\text { Local } \\
\text { Sales } \\
(\text { NLS) }\end{array}$ & & \\
\hline 22 & $\begin{array}{r}-14.3 \\
(.4)\end{array}$ & $\begin{array}{l}.018 \\
(0.1)\end{array}$ & $\begin{array}{l}18.4 \\
(3.0)\end{array}$ & $\begin{array}{l}.488 \\
(6.7)\end{array}$ & .80 & 48 \\
\hline 23 & $\begin{array}{l}25.1 \\
(0.4)\end{array}$ & $\begin{array}{l}.644 \\
(2.8)\end{array}$ & $\begin{array}{l}23.2 \\
(2.2)\end{array}$ & $\begin{array}{l}.361 \\
(1.6)\end{array}$ & .46 & 48 \\
\hline 24 & $\begin{array}{c}-2.9 \\
(0.5)\end{array}$ & $\begin{array}{l}.003 \\
(0.2)\end{array}$ & $\begin{array}{c}2.5 \\
(2.3)\end{array}$ & $\begin{array}{l}.095 \\
(1.1)\end{array}$ & .12 & 48 \\
\hline 25 & $\begin{array}{c}5.4 \\
(0.4)\end{array}$ & $\begin{array}{l}.256 \\
(5.8)\end{array}$ & $\begin{array}{c}2.6 \\
(1.1)\end{array}$ & $\begin{array}{r}-.009 \\
(0.2)\end{array}$ & .52 & 48 \\
\hline 26 & $\begin{array}{l}21.3 \\
(0.9)\end{array}$ & $\begin{array}{l}.063 \\
(0.5)\end{array}$ & $\begin{array}{c}2.0 \\
(0.5)\end{array}$ & $\begin{array}{l}.782 \\
(3.4)\end{array}$ & .56 & 48 \\
\hline 27 & $\begin{array}{r}-21.4 \\
(0.7)\end{array}$ & $\begin{array}{l}.586 \\
(5.2)\end{array}$ & $\begin{array}{l}14.9 \\
(2.8)\end{array}$ & $\begin{array}{l}.060 \\
(0.3)\end{array}$ & .59 & 48 \\
\hline 28 & $\begin{array}{c}-5.2 \\
(0.1)\end{array}$ & $\begin{array}{r}-.027 \\
(0.2)\end{array}$ & $\begin{array}{l}19.4 \\
(2.2)\end{array}$ & $\begin{array}{l}.030 \\
(1.1)\end{array}$ & .11 & 48 \\
\hline 29 & & & NA & & & \\
\hline 30 & $\begin{array}{r}-47.1 \\
(1.5)\end{array}$ & $\begin{array}{l}1.229 \\
(10.8)\end{array}$ & $\begin{array}{r}-.049 \\
(0.0)\end{array}$ & $\begin{array}{r}-4.404 \\
(5.3)\end{array}$ & .73 & 48 \\
\hline 31 & $\begin{array}{c}.0 \\
(0.0)\end{array}$ & $\begin{array}{l}.027 \\
(2.2)\end{array}$ & $\begin{array}{l}1.24 \\
(2.2)\end{array}$ & $\begin{array}{l}.077 \\
(1.8)\end{array}$ & .40 & 48 \\
\hline 32 & $\begin{array}{c}1.3 \\
(0.4)\end{array}$ & $\begin{array}{l}.031 \\
(2.4)\end{array}$ & $\begin{array}{l}1.43 \\
(2.6)\end{array}$ & $\begin{array}{l}.002 \\
(0.1)\end{array}$ & .34 & 48 \\
\hline 33 & $\begin{array}{r}-39.9 \\
(2.0)\end{array}$ & $\begin{array}{c}.803 \\
(11.1)\end{array}$ & $\begin{array}{l}13.1 \\
(3.9)\end{array}$ & $\begin{array}{l}.282 \\
(5.7)\end{array}$ & .91 & 48 \\
\hline 34 & $\begin{array}{r}-16.9 \\
(1.2)\end{array}$ & $\begin{array}{l}.147 \\
(2.8)\end{array}$ & $\begin{array}{c}6.5 \\
(2.7)\end{array}$ & $\begin{array}{l}.399 \\
(2.2)\end{array}$ & .52 & 48 \\
\hline
\end{tabular}

Notes: For definitions and industry list, see table 9.A.5. Numbers in parentheses are tstatistics. 
Table 9.A.7

OLS Equations for U.S. Exports Based on Net Local Sales and Net Export Sales by Majority-Owned U.S. Affiliates, 1982 (30 industries)

\begin{tabular}{|c|c|c|c|c|c|c|c|}
\hline \multirow[b]{2}{*}{$\begin{array}{l}\text { Industry } \\
\text { No. }\end{array}$} & \multirow[b]{2}{*}{$\begin{array}{l}\text { Intercept } \\
\text { (\$ millions) }\end{array}$} & \multicolumn{4}{|c|}{ Coefficients of } & \multirow[b]{2}{*}{$\bar{R}^{2}$} & \multirow[b]{2}{*}{$\begin{array}{l}\text { No. of } \\
\text { Obs. }\end{array}$} \\
\hline & & GDP & $\begin{array}{l}\text { GDP per } \\
\text { Capita } \\
\text { (GDPC) }\end{array}$ & $\begin{array}{l}\text { Net } \\
\text { Local } \\
\text { Sales } \\
\text { (NLS) }\end{array}$ & $\begin{array}{c}\text { Net } \\
\text { Export } \\
\text { Sales } \\
\text { (NXS) }\end{array}$ & & \\
\hline 1 & $\begin{array}{c}-3.9 \\
(0.3)\end{array}$ & $\begin{array}{l}.081 \\
(1.8)\end{array}$ & $\begin{array}{l}4.20 \\
(1.9)\end{array}$ & $\begin{array}{r}-.023 \\
(0.9)\end{array}$ & $\begin{array}{l}.383 \\
(2.0)\end{array}$ & .28 & 48 \\
\hline 2 & $\begin{array}{l}-.2 \\
(0.2)\end{array}$ & $\begin{array}{l}.016 \\
(3.8)\end{array}$ & $\begin{array}{l}.25 \\
(1.7)\end{array}$ & $\begin{array}{r}-.002 \\
(0.3)\end{array}$ & $\begin{array}{l}.004 \\
(0.4)\end{array}$ & .50 & 47 \\
\hline 3 & $\begin{array}{c}.2 \\
(0.0)\end{array}$ & $\begin{array}{l}.026 \\
(1.1)\end{array}$ & $\begin{array}{l}1.92 \\
(1.5)\end{array}$ & $\begin{array}{r}-.034 \\
(0.8)\end{array}$ & $\begin{array}{r}-.067 \\
(0.9)\end{array}$ & .02 & 43 \\
\hline 4 & $\begin{array}{l}-.4 \\
(0.0)\end{array}$ & $\begin{array}{c}1.44 \\
(11.0)\end{array}$ & $\begin{array}{l}1.00 \\
(0.1)\end{array}$ & $\begin{array}{r}-.327 \\
(4.3)\end{array}$ & $\begin{array}{l}.142 \\
(0.7)\end{array}$ & .74 & 48 \\
\hline 5 & $\begin{array}{c}1.2 \\
(0.1)\end{array}$ & $\begin{array}{l}.106 \\
(3.1)\end{array}$ & $\begin{array}{l}4.72 \\
(2.8)\end{array}$ & $\begin{array}{l}.476 \\
(3.4)\end{array}$ & $\begin{array}{l}.022 \\
(0.2)\end{array}$ & .63 & 48 \\
\hline 6 & & & NA & & & & \\
\hline 7 & & & NA & & & & \\
\hline 8 & $\begin{array}{c}2.8 \\
(0.6)\end{array}$ & $\begin{array}{l}.040 \\
(2.5)\end{array}$ & $\begin{array}{c}.91 \\
(1.1)\end{array}$ & $\begin{array}{r}-.004 \\
(0.1)\end{array}$ & $\begin{array}{r}-.046 \\
(0.3)\end{array}$ & .16 & 48 \\
\hline 9 & $\begin{array}{c}2.2 \\
(0.6)\end{array}$ & $\begin{array}{l}.028 \\
(2.2)\end{array}$ & $\begin{array}{c}.53 \\
(0.8)\end{array}$ & $\begin{array}{l}.339 \\
(4.6)\end{array}$ & $\begin{array}{l}.202 \\
(1.0)\end{array}$ & .79 & 48 \\
\hline 10 & $\begin{array}{r}-10.7 \\
(1.7)\end{array}$ & $\begin{array}{c}.527 \\
(14.1)\end{array}$ & $\begin{array}{c}.79 \\
(0.7)\end{array}$ & $\begin{array}{r}-.181 \\
(5.6)\end{array}$ & $\begin{array}{l}.037 \\
(1.0)\end{array}$ & .89 & 48 \\
\hline 11 & $\begin{array}{r}-.9 \\
(.4)\end{array}$ & $\begin{array}{l}.018 \\
(1.5)\end{array}$ & $\begin{array}{l}1.09 \\
(2.5)\end{array}$ & $\begin{array}{l}.014 \\
(1.3)\end{array}$ & $\begin{array}{r}-.008 \\
(0.3)\end{array}$ & .42 & 48 \\
\hline 12 & $\begin{array}{l}16.1 \\
(3.8)\end{array}$ & $\begin{array}{l}.073 \\
(5.3)\end{array}$ & $\begin{array}{r}-1.32 \\
(1.8)\end{array}$ & $\begin{array}{l}.230 \\
(2.8)\end{array}$ & $\begin{array}{l}.381 \\
(2.3)\end{array}$ & .61 & 47 \\
\hline 13 & $\begin{array}{l}27.8 \\
(0.8)\end{array}$ & $\begin{array}{c}1.72 \\
(13.5)\end{array}$ & $\begin{array}{r}-1.23 \\
(0.2)\end{array}$ & $\begin{array}{r}-.238 \\
(3.2)\end{array}$ & $\begin{array}{l}.131 \\
(2.6)\end{array}$ & .85 & 48 \\
\hline 14 & $\begin{array}{l}4.9 \\
(0.5)\end{array}$ & $\begin{array}{c}.32 \\
(10.3)\end{array}$ & $\begin{array}{l}1.54 \\
(1.0)\end{array}$ & $\begin{array}{c}-.035 \\
(0.7)\end{array}$ & $\begin{array}{l}.034 \\
(0.4)\end{array}$ & .77 & 48 \\
\hline 15 & $\begin{array}{c}1.7 \\
(0.4)\end{array}$ & $\begin{array}{l}.030 \\
(2.0)\end{array}$ & $\begin{array}{l}1.53 \\
(2.1)\end{array}$ & $\begin{array}{l}.032 \\
(1.6)\end{array}$ & $\begin{array}{l}.013 \\
(0.2)\end{array}$ & .32 & 48 \\
\hline 16 & $\begin{array}{c}-2.1 \\
(0.7)\end{array}$ & $\begin{array}{l}.032 \\
(2.55)\end{array}$ & $\begin{array}{l}1.50 \\
(2.9)\end{array}$ & $\begin{array}{l}.056 \\
(1.5)\end{array}$ & $\begin{array}{l}.017 \\
(0.4)\end{array}$ & .55 & 48 \\
\hline 17 & $\begin{array}{l}13.7 \\
(0.7)\end{array}$ & $\begin{array}{l}.037 \\
(0.6)\end{array}$ & $\begin{array}{l}4.22 \\
(1.3)\end{array}$ & $\begin{array}{l}.183 \\
(0.5)\end{array}$ & $\begin{array}{c}-1.111 \\
(0.88)\end{array}$ & -.02 & 48 \\
\hline 18 & $\begin{array}{r}-21.0 \\
(2.0)\end{array}$ & $\begin{array}{c}.554 \\
(14.0)\end{array}$ & $\begin{array}{l}2.98 \\
(1.6)\end{array}$ & $\begin{array}{r}-.583 \\
(3.4)\end{array}$ & $\begin{array}{l}.108 \\
(0.4)\end{array}$ & .85 & 48 \\
\hline 19 & $\begin{array}{c}-3.4 \\
(0.1)\end{array}$ & $\begin{array}{l}.167 \\
(1.7)\end{array}$ & $\begin{array}{l}9.09 \\
(2.0)\end{array}$ & $\begin{array}{l}.143 \\
(1.1)\end{array}$ & $\begin{array}{r}-.313 \\
(0.9)\end{array}$ & .20 & 48 \\
\hline 20 & & & NA & & & & \\
\hline
\end{tabular}


Table 9.A.7 (continued)

\begin{tabular}{|c|c|c|c|c|c|c|c|}
\hline \multirow[b]{2}{*}{$\begin{array}{l}\text { Industry } \\
\text { No. }\end{array}$} & \multirow[b]{2}{*}{$\begin{array}{l}\text { Intercept } \\
\text { (\$ millions) }\end{array}$} & \multicolumn{4}{|c|}{ Coefficients of } & \multirow[b]{2}{*}{$\bar{R}^{2}$} & \multirow[b]{2}{*}{$\begin{array}{l}\text { No. of } \\
\text { Obs. }\end{array}$} \\
\hline & & GDP & $\begin{array}{c}\text { GDP per } \\
\text { Capita } \\
\text { (GDPC) }\end{array}$ & $\begin{array}{c}\text { Net } \\
\text { Local } \\
\text { Sales } \\
\text { (NLS) }\end{array}$ & $\begin{array}{c}\text { Net } \\
\text { Export } \\
\text { Sales } \\
\text { (NXS) }\end{array}$ & & \\
\hline 21 & $\begin{array}{l}30.3 \\
(1.0)\end{array}$ & $\begin{array}{l}.021 \\
(0.2)\end{array}$ & $\begin{array}{c}8.0 \\
(1.6)\end{array}$ & $\begin{array}{l}.208 \\
(1.5)\end{array}$ & $\begin{array}{r}-.062 \\
(0.4)\end{array}$ & .07 & 48 \\
\hline 22 & $\begin{array}{r}-23.6 \\
(0.7)\end{array}$ & $\begin{array}{l}.238 \\
(1.1)\end{array}$ & $\begin{array}{l}16.2 \\
(2.8)\end{array}$ & $\begin{array}{l}.146 \\
(1.0)\end{array}$ & $\begin{array}{l}.440 \\
(2.6)\end{array}$ & .83 & 48 \\
\hline 23 & $\begin{array}{l}16.9 \\
(0.3)\end{array}$ & $\begin{array}{l}.589 \\
(2.5)\end{array}$ & $\begin{array}{l}26.2 \\
(2.4)\end{array}$ & $\begin{array}{l}.778 \\
(1.5)\end{array}$ & $\begin{array}{r}-.529 \\
(0.9)\end{array}$ & .46 & 48 \\
\hline 24 & $\begin{array}{c}-3.4 \\
(0.5)\end{array}$ & $\begin{array}{l}.010 \\
(0.4)\end{array}$ & $\begin{array}{l}2.61 \\
(2.4)\end{array}$ & $\begin{array}{l}.113 \\
(1.2)\end{array}$ & $\begin{array}{r}-.114 \\
(0.9)\end{array}$ & .12 & 48 \\
\hline 25 & $\begin{array}{c}4.6 \\
(0.4)\end{array}$ & $\begin{array}{l}.257 \\
(5.9)\end{array}$ & $\begin{array}{c}2.6 \\
(1.2)\end{array}$ & $\begin{array}{r}-.164 \\
(1.7)\end{array}$ & $\begin{array}{l}.402 \\
(1.7)\end{array}$ & .54 & 48 \\
\hline 26 & $\begin{array}{c}-5.4 \\
(0.3)\end{array}$ & $\begin{array}{l}.368 \\
(3.5)\end{array}$ & $\begin{array}{c}-.56 \\
(0.2)\end{array}$ & $\begin{array}{r}-.004 \\
(0.0)\end{array}$ & $\begin{array}{l}.721 \\
(6.9)\end{array}$ & .79 & 48 \\
\hline 27 & $\begin{array}{r}-18.8 \\
(0.6)\end{array}$ & $\begin{array}{l}.584 \\
(5.2)\end{array}$ & $\begin{array}{l}13.9 \\
(2.4)\end{array}$ & $\begin{array}{r}-.007 \\
(0.0)\end{array}$ & $\begin{array}{l}.280 \\
(0.5)\end{array}$ & .58 & 48 \\
\hline 28 & $\begin{array}{r}-10.4 \\
(0.2)\end{array}$ & $\begin{array}{r}-.003 \\
(0.0)\end{array}$ & $\begin{array}{l}19.7 \\
(2.3)\end{array}$ & $\begin{array}{l}.048 \\
(1.4)\end{array}$ & $\begin{array}{r}-.035 \\
(0.8)\end{array}$ & .10 & 48 \\
\hline 29 & & & NA & & & & \\
\hline 30 & $\begin{array}{r}-32.2 \\
(1.0)\end{array}$ & $\begin{array}{l}1.280 \\
(11.5)\end{array}$ & $\begin{array}{c}-2.3 \\
(0.4)\end{array}$ & $\begin{array}{r}-3.025 \\
(3.0)\end{array}$ & $\begin{array}{r}-7.130 \\
(2.3)\end{array}$ & .75 & 48 \\
\hline 31 & $\begin{array}{l}-.2 \\
(0.1)\end{array}$ & $\begin{array}{l}.027 \\
(2.3)\end{array}$ & $\begin{array}{l}1.31 \\
(2.3)\end{array}$ & $\begin{array}{l}.087 \\
(1.8)\end{array}$ & $\begin{array}{r}-.037 \\
(0.5)\end{array}$ & .39 & 48 \\
\hline 32 & $\begin{array}{l}1.7 \\
(.5)\end{array}$ & $\begin{array}{l}.027 \\
(2.1)\end{array}$ & $\begin{array}{l}1.61 \\
(2.9)\end{array}$ & $\begin{array}{l}.043 \\
(0.8)\end{array}$ & $\begin{array}{r}-.127 \\
(1.1)\end{array}$ & .35 & 48 \\
\hline 33 & $\begin{array}{r}-41.8 \\
(2.5)\end{array}$ & $\begin{array}{c}.904 \\
(13.5)\end{array}$ & $\begin{array}{r}11.88 \\
(4.1)\end{array}$ & $\begin{array}{r}-.053 \\
(0.6)\end{array}$ & $\begin{array}{l}.378 \\
(4.0)\end{array}$ & .93 & 48 \\
\hline 34 & $\begin{array}{r}-16.0 \\
(1.1)\end{array}$ & $\begin{array}{l}.135 \\
(2.4)\end{array}$ & $\begin{array}{l}6.20 \\
(2.5)\end{array}$ & $\begin{array}{l}.363 \\
(1.9)\end{array}$ & $\begin{array}{l}.290 \\
(0.6)\end{array}$ & .52 & 48 \\
\hline
\end{tabular}

Notes: For definitions and industry list, see table 9.A.5. Numbers in parentheses are tstatistics. 
Table 9.A.8

OLS Equations for U.S. Exports Based on Production by

Majority-Owned U.S. Affiliates, 1982 (6 industry groups)

\begin{tabular}{|c|c|c|c|c|c|c|c|c|}
\hline $\begin{array}{l}\text { Industry } \\
\text { Group }\end{array}$ & Intercept & GDP & $\begin{array}{c}\text { GDP } \\
\text { per } \\
\text { Capita } \\
\text { (GDPC) }\end{array}$ & $\begin{array}{l}\text { Net } \\
\text { Sales } \\
\text { (NS) }\end{array}$ & $\begin{array}{c}\text { Net } \\
\text { Local } \\
\text { Sales } \\
\text { (NLS) }\end{array}$ & $\begin{array}{c}\text { Net } \\
\text { Export } \\
\text { Sales } \\
\text { (NXS) }\end{array}$ & $\bar{R}^{2}$ & $\begin{array}{c}\text { No. of } \\
\text { Obs. }\end{array}$ \\
\hline$A$ & $\begin{array}{c}-54.6 \\
(0.89)\end{array}$ & $\begin{array}{c}1.80 \\
(11.16)\end{array}$ & $\begin{array}{c}5.98 \\
(0.52)\end{array}$ & $\begin{array}{c}-135.4 \\
(4.26)\end{array}$ & & & .87 & 23 \\
\hline B & $\begin{array}{c}17.7 \\
(0.21)\end{array}$ & $\begin{array}{c}2.53 \\
(11.22)\end{array}$ & $\begin{array}{l}11.85 \\
(0.83)\end{array}$ & $\begin{array}{r}-60.90 \\
(1.96)\end{array}$ & & & .87 & 27 \\
\hline C & $\begin{array}{c}7.9 \\
(0.15)\end{array}$ & $\begin{array}{c}.80 \\
(7.10)\end{array}$ & $\begin{array}{c}2.03 \\
(0.26)\end{array}$ & $\begin{array}{c}-6.99 \\
(0.17)\end{array}$ & & & .78 & 20 \\
\hline D & $\begin{array}{c}66.8 \\
(0.36)\end{array}$ & $\begin{array}{c}.59 \\
(0.46)\end{array}$ & $\begin{array}{l}48.14 \\
(1.88)\end{array}$ & $\begin{array}{l}222.1 \\
(1.80)\end{array}$ & & & .64 & 26 \\
\hline E & $\begin{array}{l}156.2 \\
(1.31)\end{array}$ & $\begin{array}{c}1.14 \\
(3.80)\end{array}$ & $\begin{array}{c}-9.50 \\
(0.48)\end{array}$ & $\begin{array}{l}155.6 \\
(1.56)\end{array}$ & & & .59 & 24 \\
\hline F & $\begin{array}{c}-81.1 \\
(0.67)\end{array}$ & $\begin{array}{c}.88 \\
(2.82)\end{array}$ & $\begin{array}{l}51.24 \\
(2.83)\end{array}$ & $\begin{array}{c}5.92 \\
(0.22)\end{array}$ & & & .52 & 24 \\
\hline B & $\begin{array}{c}21.9 \\
(0.20)\end{array}$ & $\begin{array}{c}2.88 \\
(11.0)\end{array}$ & $\begin{array}{l}17.92 \\
(0.88)\end{array}$ & & $\begin{array}{r}-202.2 \\
(3.82)\end{array}$ & & .92 & 17 \\
\hline D & $\begin{array}{c}20.0 \\
(0.10)\end{array}$ & $\begin{array}{c}.92 \\
(0.52)\end{array}$ & $\begin{array}{l}55.52 \\
(2.09)\end{array}$ & & $\begin{array}{l}334.3 \\
(1.13)\end{array}$ & & .63 & 24 \\
\hline E & $\begin{array}{l}103.0 \\
(0.76)\end{array}$ & $\begin{array}{c}1.07 \\
(3.09)\end{array}$ & $\begin{array}{c}6.99 \\
(0.30)\end{array}$ & & $\begin{array}{l}185.8 \\
(1.10)\end{array}$ & & .61 & 18 \\
\hline $\mathbf{F}$ & $\begin{array}{r}-72.0 \\
(0.56)\end{array}$ & $\begin{array}{c}.92 \\
(2.88)\end{array}$ & $\begin{array}{l}48.35 \\
(2.54)\end{array}$ & & $\begin{array}{l}19.15 \\
(0.40)\end{array}$ & & .53 & 22 \\
\hline B & $\begin{array}{l}110.2 \\
(0.94)\end{array}$ & $\begin{array}{c}3.11 \\
(10.80)\end{array}$ & $\begin{array}{r}-10.84 \\
(0.41)\end{array}$ & & $\begin{array}{r}-255.3 \\
(4.26)\end{array}$ & $\begin{array}{l}125.3 \\
(1.56)\end{array}$ & .92 & 17 \\
\hline D & $\begin{array}{c}48.1 \\
(0.24)\end{array}$ & $\begin{array}{c}1.22 \\
(0.68)\end{array}$ & $\begin{array}{l}45.46 \\
(1.57)\end{array}$ & & $\begin{array}{c}50.1 \\
(0.12)\end{array}$ & $\begin{array}{l}312.7 \\
(0.90)\end{array}$ & .62 & 24 \\
\hline $\mathrm{E}$ & $\begin{array}{c}44.9 \\
(0.39)\end{array}$ & $\begin{array}{c}1.32 \\
(4.34)\end{array}$ & $\begin{array}{c}4.64 \\
(0.24)\end{array}$ & & $\begin{array}{r}-303.3 \\
(1.32)\end{array}$ & $\begin{array}{l}914.6 \\
(2.73)\end{array}$ & .73 & 18 \\
\hline $\mathbf{F}$ & $\begin{array}{r}-75.0 \\
(0.57)\end{array}$ & $\begin{array}{c}.93 \\
(2.83)\end{array}$ & $\begin{array}{l}48.64 \\
(2.49)\end{array}$ & & $\begin{array}{c}37.0 \\
(0.50)\end{array}$ & $\begin{array}{c}-27.6 \\
(0.32)\end{array}$ & .51 & 22 \\
\hline
\end{tabular}

Notes: Industry groups defined in terms of the industries of Table 9.A.5 are: (A) foods and kindred products (nos. 1-4); (B) chemicals and allied products (nos. 10-14); (C) metals (nos. 17-19); (D) Nonelectrical machinery (nos. 20-23); (E) electrical machinery (nos. 24-27); and (F) transport equipment (nos. 28 and 29). 
OLS Equations for U.S. Exports Based on Production by Both MajorityOwned and Minority-Owned U.S. Affiliates, 1982 (6 industry groups)

\begin{tabular}{|c|c|c|c|c|c|c|c|c|c|}
\hline \multirow[b]{3}{*}{$\begin{array}{l}\text { Industry } \\
\text { Group }\end{array}$} & \multirow[b]{3}{*}{ Intercept } & \multicolumn{6}{|c|}{ Coefficients of } & \multirow[b]{3}{*}{$\bar{R}^{2}$} & \multirow[b]{3}{*}{$\begin{array}{l}\text { No. of } \\
\text { Obs. }\end{array}$} \\
\hline & & \multirow{2}{*}{\multicolumn{2}{|c|}{$\begin{array}{cc} & \text { GDP per } \\
& \text { Capita } \\
\text { GDP } & \text { (GDPC) }\end{array}$}} & \multicolumn{3}{|c|}{ Majority-Owned Affiliate } & \multirow[b]{2}{*}{$\begin{array}{l}\text { Minority- } \\
\text { Owned } \\
\text { Affiliate } \\
\text { Net Sales } \\
\text { (MONS) }\end{array}$} & & \\
\hline & & & & $\begin{array}{l}\text { Net } \\
\text { Sales } \\
\text { (NS) }\end{array}$ & $\begin{array}{c}\text { Net } \\
\text { Local } \\
\text { Sales } \\
(\text { NLS) }\end{array}$ & $\begin{array}{c}\text { Net } \\
\text { Export } \\
\text { Sales } \\
\text { (NXS) }\end{array}$ & & & \\
\hline A & $\begin{array}{c}-58.6 \\
(0.91)\end{array}$ & $\begin{array}{c}1.75 \\
(6.85)\end{array}$ & $\begin{array}{c}8.05 \\
(0.64)\end{array}$ & $\begin{array}{r}-133.6 \\
(3.54)\end{array}$ & & & $\begin{array}{c}25.4 \\
(0.20)\end{array}$ & .86 & 22 \\
\hline B & $\begin{array}{l}100.0 \\
(1.88)\end{array}$ & $\begin{array}{c}1.02 \\
(3.82)\end{array}$ & $\begin{array}{c}3.04 \\
(0.35)\end{array}$ & $\begin{array}{c}15.5 \\
(0.70)\end{array}$ & & & $\begin{array}{l}417.0 \\
(6.55)\end{array}$ & .95 & 27 \\
\hline $\mathrm{C}$ & $\begin{array}{c}-34.8 \\
(0.63)\end{array}$ & $\begin{array}{c}.75 \\
(5.37)\end{array}$ & $\begin{array}{c}5.17 \\
(0.65)\end{array}$ & $\begin{array}{c}2.7 \\
(0.07)\end{array}$ & & & $\begin{array}{c}66.4 \\
(0.66)\end{array}$ & .81 & 18 \\
\hline $\mathrm{D}$ & $\begin{array}{l}277.3 \\
(2.41)\end{array}$ & $\begin{array}{l}-.44 \\
(0.54)\end{array}$ & $\begin{array}{c}2.28 \\
(0.13)\end{array}$ & $\begin{array}{l}289.2 \\
(3.03)\end{array}$ & & & $\begin{array}{l}546.9 \\
(1.37)\end{array}$ & .85 & 24 \\
\hline $\mathrm{E}$ & $\begin{array}{l}149.0 \\
(1.28)\end{array}$ & $\begin{array}{c}.85 \\
(2.38)\end{array}$ & $\begin{array}{c}-7.03 \\
(0.36)\end{array}$ & $\begin{array}{l}142.3 \\
(1.45)\end{array}$ & & & $\begin{array}{l}320.2 \\
(1.40)\end{array}$ & .61 & 24 \\
\hline $\mathrm{F}$ & $\begin{array}{c}34.9 \\
(0.61)\end{array}$ & $\begin{array}{c}.36 \\
(1.26)\end{array}$ & $\begin{array}{l}18.53 \\
(2.31)\end{array}$ & $\begin{array}{c}50.0 \\
(3.00)\end{array}$ & & & $\begin{array}{c}43.8 \\
(1.92)\end{array}$ & .86 & 19 \\
\hline B & $\begin{array}{c}18.7 \\
(0.26)\end{array}$ & $\begin{array}{c}1.42 \\
(3.79)\end{array}$ & $\begin{array}{l}26.20 \\
(1.94)\end{array}$ & & $\begin{array}{r}-74.9 \\
(1.66)\end{array}$ & & $\begin{array}{l}335.9 \\
(4.40)\end{array}$ & .96 & 17 \\
\hline D & $\begin{array}{l}224.0 \\
(1.65)\end{array}$ & $\begin{array}{l}-.33 \\
(0.27)\end{array}$ & $\begin{array}{l}13.06 \\
(0.68)\end{array}$ & & $\begin{array}{l}424.7 \\
(1.81)\end{array}$ & & $\begin{array}{l}769.5 \\
(1.70)\end{array}$ & .82 & 22 \\
\hline $\mathrm{E}$ & $\begin{array}{c}90.0 \\
(0.67)\end{array}$ & $\begin{array}{c}.85 \\
(2.16)\end{array}$ & $\begin{array}{c}9.65 \\
(0.42)\end{array}$ & & $\begin{array}{l}142.0 \\
(0.83)\end{array}$ & & $\begin{array}{l}289.6 \\
(1.16)\end{array}$ & .62 & 18 \\
\hline $\mathrm{F}$ & $\begin{array}{c}18.3 \\
(0.40)\end{array}$ & $\begin{array}{c}.73 \\
(3.23)\end{array}$ & $\begin{array}{l}16.17 \\
(2.46)\end{array}$ & & $\begin{array}{c}65.0 \\
(3.04)\end{array}$ & & $\begin{array}{c}18.1 \\
(1.02)\end{array}$ & .92 & 17 \\
\hline B & $\begin{array}{l}108.3 \\
(1.68)\end{array}$ & $\begin{array}{c}1.64 \\
(5.32)\end{array}$ & $\begin{array}{c}-2.93 \\
(0.20)\end{array}$ & & $\begin{array}{r}-124.0 \\
(3.11)\end{array}$ & $\begin{array}{l}127.1 \\
(2.90)\end{array}$ & $\begin{array}{l}337.1 \\
(5.54)\end{array}$ & .98 & 17 \\
\hline $\mathrm{D}$ & $\begin{array}{l}268.3 \\
(2.11)\end{array}$ & $\begin{array}{c}.06 \\
(0.05)\end{array}$ & $\begin{array}{r}-3.40 \\
(0.17)\end{array}$ & & $\begin{array}{c}85.2 \\
(0.31)\end{array}$ & $\begin{array}{l}440.7 \\
(2.03)\end{array}$ & $\begin{array}{l}586.7 \\
(1.34)\end{array}$ & .85 & 22 \\
\hline $\mathrm{E}$ & $\begin{array}{l}-6.3 \\
(0.07)\end{array}$ & $\begin{array}{c}.95 \\
(3.88)\end{array}$ & $\begin{array}{c}9.25 \\
(0.64)\end{array}$ & & $\begin{array}{r}-595.4 \\
(3.19)\end{array}$ & $\begin{array}{r}1,289.0 \\
(4.81)\end{array}$ & $\begin{array}{l}606.3 \\
(3.59)\end{array}$ & .85 & 18 \\
\hline $\mathrm{F}$ & $\begin{array}{c}23.1 \\
(0.48)\end{array}$ & $\begin{array}{c}.67 \\
(2.59)\end{array}$ & $\begin{array}{l}16.03 \\
(2.37)\end{array}$ & & $\begin{array}{c}59.2 \\
(2.42)\end{array}$ & $\begin{array}{c}15.5 \\
(0.55)\end{array}$ & $\begin{array}{c}22.6 \\
(1.13)\end{array}$ & .92 & 17 \\
\hline
\end{tabular}

Notes: See Table 9.A.8. 
Table 9.A.10

OLS Equations for Non-U.S. Exports Based on Net Sales by Majority-Owned U.S. Affiliates, 1982 (30 industries)

\begin{tabular}{|c|c|c|c|c|c|c|}
\hline \multirow[b]{2}{*}{$\begin{array}{l}\text { Industry } \\
\text { No. }\end{array}$} & \multirow[b]{2}{*}{$\begin{array}{l}\text { Intercept } \\
\text { (\$ millions) }\end{array}$} & \multicolumn{3}{|c|}{ Coefficients of } & \multirow[b]{2}{*}{$\bar{R}^{2}$} & \multirow[b]{2}{*}{$\begin{array}{c}\text { No. of } \\
\text { Obs. }\end{array}$} \\
\hline & & GDP & $\begin{array}{l}\text { GDP per } \\
\text { Capita } \\
\text { (GDPC) }\end{array}$ & $\begin{array}{l}\text { Net } \\
\text { Sales } \\
\text { (NS) }\end{array}$ & & \\
\hline 1 & $\begin{array}{c}-11 \\
(.5)\end{array}$ & $\begin{array}{c}.07 \\
(1.0)\end{array}$ & $\begin{array}{l}14.6 \\
(3.5)\end{array}$ & $\begin{array}{c}.12 \\
(3.3)\end{array}$ & .49 & 48 \\
\hline 2 & $\begin{array}{l}-68 \\
(1.9)\end{array}$ & $\begin{array}{c}.34 \\
(2.2)\end{array}$ & $\begin{array}{l}19.6 \\
(3.2)\end{array}$ & $\begin{array}{c}.58 \\
(3.1)\end{array}$ & .65 & 47 \\
\hline 3 & $\begin{array}{r}-19 \\
(.9)\end{array}$ & $\begin{array}{c}.16 \\
(2.4)\end{array}$ & $\begin{array}{c}6.6 \\
(1.8)\end{array}$ & $\begin{array}{l}.05 \\
(.5)\end{array}$ & .26 & 43 \\
\hline 4 & $\begin{array}{c}-541 \\
(1.9)\end{array}$ & $\begin{array}{l}6.94 \\
(6.9)\end{array}$ & $\begin{array}{c}131.1 \\
(2.6)\end{array}$ & $\begin{array}{l}1.52 \\
(3.3)\end{array}$ & .77 & 48 \\
\hline 5 & $\begin{array}{c}-596 \\
(1.8)\end{array}$ & $\begin{array}{l}4.15 \\
(3.9)\end{array}$ & $\begin{array}{c}183.6 \\
(3.2)\end{array}$ & $\begin{array}{l}8.05 \\
(3.4)\end{array}$ & .63 & 48 \\
\hline 6 & & & NA & & & \\
\hline 7 & & & NA & & & \\
\hline 8 & $\begin{array}{l}-41 \\
(1.9)\end{array}$ & $\begin{array}{c}.08 \\
(1.1)\end{array}$ & $\begin{array}{l}16.1 \\
(4.3)\end{array}$ & $\begin{array}{c}.24 \\
(2.2)\end{array}$ & .47 & 48 \\
\hline 9 & $\begin{array}{l}-36 \\
(1.3)\end{array}$ & $\begin{array}{l}.10 \\
(1.1)\end{array}$ & $\begin{array}{l}19.8 \\
(4.7)\end{array}$ & $\begin{array}{c}.77 \\
(3.5)\end{array}$ & .56 & 48 \\
\hline 10 & $\begin{array}{l}-35 \\
(1.5)\end{array}$ & $\begin{array}{c}.50 \\
(4.6)\end{array}$ & $\begin{array}{l}23.1 \\
(5.6)\end{array}$ & $\begin{array}{c}.15 \\
(2.6)\end{array}$ & .81 & 48 \\
\hline 11 & $\begin{array}{l}-33 \\
(2.2)\end{array}$ & $\begin{array}{c}-.03 \\
(0.4)\end{array}$ & $\begin{array}{l}15.3 \\
(5.9)\end{array}$ & $\begin{array}{c}.18 \\
(4.1)\end{array}$ & .69 & 48 \\
\hline 12 & $\begin{array}{l}-22 \\
(0.6)\end{array}$ & $\begin{array}{c}.32 \\
(2.7)\end{array}$ & $\begin{array}{l}12.0 \\
(2.0)\end{array}$ & $\begin{array}{c}.99 \\
(1.9)\end{array}$ & .37 & 47 \\
\hline 13 & $\begin{array}{c}-159 \\
(0.7)\end{array}$ & $\begin{array}{c}3.6 \\
(4.4)\end{array}$ & $\begin{array}{l}96.0 \\
(2.3)\end{array}$ & $\begin{array}{l}1.13 \\
(5.2)\end{array}$ & .74 & 48 \\
\hline 14 & $\begin{array}{l}-46 \\
(1.3)\end{array}$ & $\begin{array}{c}.56 \\
(4.7)\end{array}$ & $\begin{array}{l}27.3 \\
(4.4)\end{array}$ & $\begin{array}{c}.35 \\
(3.7)\end{array}$ & .73 & 48 \\
\hline 15 & $\begin{array}{l}-85 \\
(2.2)\end{array}$ & $\begin{array}{c}.31 \\
(2.2)\end{array}$ & $\begin{array}{l}31.2 \\
(4.7)\end{array}$ & $\begin{array}{c}.32 \\
(2.1)\end{array}$ & .55 & 48 \\
\hline 16 & $\begin{array}{l}-52 \\
(2.2)\end{array}$ & $\begin{array}{c}-.09 \\
(0.9)\end{array}$ & $\begin{array}{l}19.1 \\
(4.7)\end{array}$ & $\begin{array}{l}1.37 \\
(6.7)\end{array}$ & .74 & 48 \\
\hline 17 & $\begin{array}{r}-210 \\
(1.2)\end{array}$ & $\begin{array}{l}1.46 \\
(2.2)\end{array}$ & $\begin{array}{r}137.9 \\
(4.4)\end{array}$ & $\begin{array}{l}9.31 \\
(3.4)\end{array}$ & .62 & 48 \\
\hline 18 & $\begin{array}{r}-229 \\
(2.5)\end{array}$ & $\begin{array}{l}2.71 \\
(7.9)\end{array}$ & $\begin{array}{l}58.1 \\
(3.6)\end{array}$ & $\begin{array}{l}3.93 \\
(4.6)\end{array}$ & .85 & 48 \\
\hline 19 & $\begin{array}{c}-132 \\
(1.5)\end{array}$ & $\begin{array}{c}-.01 \\
(.03)\end{array}$ & $\begin{array}{l}88.8 \\
(5.9)\end{array}$ & $\begin{array}{c}.69 \\
(4.5)\end{array}$ & .66 & 48 \\
\hline 20 & & & NA & & & \\
\hline
\end{tabular}


Table 9.A.10 (continued)

\begin{tabular}{|c|c|c|c|c|c|c|}
\hline \multirow[b]{2}{*}{$\begin{array}{l}\text { Industry } \\
\text { No. }\end{array}$} & \multirow[b]{2}{*}{$\begin{array}{c}\text { Intercept } \\
\text { (\$ millions) }\end{array}$} & \multicolumn{3}{|c|}{ Coefficients of } & \multirow[b]{2}{*}{$\bar{R}^{2}$} & \multirow[b]{2}{*}{$\begin{array}{l}\text { No. of } \\
\text { Obs. }\end{array}$} \\
\hline & & GDP & $\begin{array}{c}\text { GDP per } \\
\text { Capita } \\
\text { (GDPC) }\end{array}$ & $\begin{array}{c}\text { Net } \\
\text { Sales } \\
\text { (NS) }\end{array}$ & & \\
\hline 21 & $\begin{array}{c}.5 \\
(0.0)\end{array}$ & $\begin{array}{l}.05 \\
(.3)\end{array}$ & $\begin{array}{l}33.7 \\
(4.2)\end{array}$ & $\begin{array}{c}.45 \\
(3.7)\end{array}$ & .54 & 48 \\
\hline 22 & $\begin{array}{l}-12 \\
(0.3)\end{array}$ & $\begin{array}{r}-.79 \\
(4.2)\end{array}$ & $\begin{array}{l}31.8 \\
(4.7)\end{array}$ & $\begin{array}{c}.58 \\
(13.2)\end{array}$ & .89 & 48 \\
\hline 23 & $\begin{array}{c}-424 \\
(0.0)\end{array}$ & $\begin{array}{l}1.18 \\
(2.0)\end{array}$ & $\begin{array}{r}125.0 \\
(4.5)\end{array}$ & $\begin{array}{l}1.67 \\
(5.1)\end{array}$ & .72 & 48 \\
\hline 24 & $\begin{array}{l}-49 \\
(1.7)\end{array}$ & $\begin{array}{l}.08 \\
(.7)\end{array}$ & $\begin{array}{l}24.5 \\
(4.8)\end{array}$ & $\begin{array}{l}1.90 \\
(6.2)\end{array}$ & .71 & 48 \\
\hline 25 & $\begin{array}{l}-53 \\
(0.5)\end{array}$ & $\begin{array}{c}.63 \\
(2.0)\end{array}$ & $\begin{array}{l}51.1 \\
(3.1)\end{array}$ & $\begin{array}{l}.75 \\
(3.9)\end{array}$ & .57 & 48 \\
\hline 26 & $\begin{array}{c}-8 \\
(0.3)\end{array}$ & $\begin{array}{r}-.09 \\
(.7)\end{array}$ & $\begin{array}{l}15.1 \\
(2.8)\end{array}$ & $\begin{array}{c}1.40 \\
(11.9)\end{array}$ & .85 & 48 \\
\hline 27 & $\begin{array}{r}-114 \\
(1.3)\end{array}$ & $\begin{array}{c}.76 \\
(2.4)\end{array}$ & $\begin{array}{l}78.4 \\
(5.0)\end{array}$ & $\begin{array}{l}1.50 \\
(3.3)\end{array}$ & .65 & 48 \\
\hline 28 & $\begin{array}{c}-385 \\
(1.1)\end{array}$ & $\begin{array}{l}1.78 \\
(1.5)\end{array}$ & $\begin{array}{r}240.5 \\
(4.0)\end{array}$ & $\begin{array}{c}.39 \\
(3.5)\end{array}$ & .55 & 48 \\
\hline 29 & & & NA & & & \\
\hline 30 & $\begin{array}{r}-286 \\
(3.4)\end{array}$ & $\begin{array}{c}3.28 \\
(10.7)\end{array}$ & $\begin{array}{l}69.7 \\
(4.8)\end{array}$ & $\begin{array}{c}.61 \\
(0.3)\end{array}$ & .85 & 48 \\
\hline 31 & $\begin{array}{r}-20.7 \\
(1.3)\end{array}$ & $\begin{array}{c}.07 \\
(1.1)\end{array}$ & $\begin{array}{l}13.9 \\
(4.9)\end{array}$ & $\begin{array}{l}1.19 \\
(7.6)\end{array}$ & .79 & 48 \\
\hline 32 & $\begin{array}{c}-51 \\
(1.0)\end{array}$ & $\begin{array}{c}-.02 \\
(0.1)\end{array}$ & $\begin{array}{l}35.1 \\
(3.8)\end{array}$ & $\begin{array}{l}1.88 \\
(3.8)\end{array}$ & .54 & 48 \\
\hline 33 & $\begin{array}{c}-106 \\
(1.2)\end{array}$ & $\begin{array}{c}.81 \\
(2.7)\end{array}$ & $\begin{array}{l}65.8 \\
(4.4)\end{array}$ & $\begin{array}{l}.75 \\
(6.7)\end{array}$ & .77 & 48 \\
\hline 34 & $\begin{array}{c}-204 \\
(1.6)\end{array}$ & $\begin{array}{c}.12 \\
(0.2)\end{array}$ & $\begin{array}{l}90.0 \\
(4.2)\end{array}$ & $\begin{array}{l}4.58 \\
(3.5)\end{array}$ & .56 & 48 \\
\hline
\end{tabular}

Notes: Dependent variable is exports to a country by an industry from countries other than the U.S. For definitions and industry list, see Table 9.A.5. Numbers in parentheses are t-statistics. 
Table 9.A.11 OLS Equations for Non-U.S. Exports Based on Net Local Sales by Majority-Owned U.S. Affiliates, 1982 (30 industries)

\begin{tabular}{|c|c|c|c|c|c|c|}
\hline \multirow[b]{2}{*}{$\begin{array}{l}\text { Industry } \\
\text { No. }\end{array}$} & \multirow[b]{2}{*}{$\begin{array}{l}\text { Intercept } \\
\text { ( } \$ \text { millions) }\end{array}$} & \multicolumn{3}{|c|}{ Coefficients of } & \multirow[b]{2}{*}{$\bar{R}^{2}$} & \multirow[b]{2}{*}{$\begin{array}{l}\text { No. of } \\
\text { Obs. }\end{array}$} \\
\hline & & GDP & $\begin{array}{c}\text { GDP per } \\
\text { Capita } \\
\text { (GDPC) }\end{array}$ & $\begin{array}{l}\text { Net } \\
\text { Local } \\
\text { Sales } \\
\text { (NLS) }\end{array}$ & & \\
\hline 1 & $\begin{array}{l}-11 \\
(0.5)\end{array}$ & $\begin{array}{c}.10 \\
(1.2)\end{array}$ & $\begin{array}{c}14.71 \\
(3.5)\end{array}$ & $\begin{array}{l}.12 \\
(3.1)\end{array}$ & .47 & 48 \\
\hline 2 & $\begin{array}{l}-68 \\
(1.8)\end{array}$ & $\begin{array}{l}.48 \\
(2.7)\end{array}$ & $\begin{array}{c}20.92 \\
(3.2)\end{array}$ & $\begin{array}{l}.36 \\
(1.4)\end{array}$ & .59 & 47 \\
\hline 3 & $\begin{array}{l}-21 \\
(1.0)\end{array}$ & $\begin{array}{c}.17 \\
(2.6)\end{array}$ & $\begin{array}{l}7.21 \\
(2.0)\end{array}$ & $\begin{array}{c}-.03 \\
(0.2)\end{array}$ & .26 & 43 \\
\hline 4 & $\begin{array}{r}-555 \\
(1.9)\end{array}$ & $\begin{array}{l}7.10 \\
(6.7)\end{array}$ & $\begin{array}{r}143.57 \\
(2.8)\end{array}$ & $\begin{array}{l}1.56 \\
(2.7)\end{array}$ & .75 & 48 \\
\hline 5 & $\begin{array}{r}-655 \\
(1.9)\end{array}$ & $\begin{array}{l}3.81 \\
(3.0)\end{array}$ & $\begin{array}{r}222.75 \\
(3.7)\end{array}$ & $\begin{array}{r}11.55 \\
(2.3)\end{array}$ & .59 & 48 \\
\hline 6 & & & NA & & & \\
\hline 7 & & & NA & & & \\
\hline 8 & $\begin{array}{l}-40 \\
(1.8)\end{array}$ & $\begin{array}{c}.12 \\
(1.4)\end{array}$ & $\begin{array}{c}16.50 \\
(4.3)\end{array}$ & $\begin{array}{c}.16 \\
(1.3)\end{array}$ & .44 & 48 \\
\hline 9 & $\begin{array}{l}-34 \\
(1.3)\end{array}$ & $\begin{array}{l}.10 \\
(1.2)\end{array}$ & $\begin{array}{c}19.39 \\
(4.1)\end{array}$ & $\begin{array}{l}1.02 \\
(3.5)\end{array}$ & .57 & 48 \\
\hline 10 & $\begin{array}{l}-37 \\
(1.5)\end{array}$ & $\begin{array}{c}.51 \\
(3.8)\end{array}$ & $\begin{array}{r}24.30 \\
(5.7)\end{array}$ & $\begin{array}{c}.16 \\
(1.7)\end{array}$ & .79 & 48 \\
\hline 11 & $\begin{array}{l}-36 \\
(2.2)\end{array}$ & $\begin{array}{c}.02 \\
(0.3)\end{array}$ & $\begin{array}{l}16.2 \\
(5.8)\end{array}$ & $\begin{array}{l}.16 \\
(2.6)\end{array}$ & .62 & 48 \\
\hline 12 & $\begin{array}{l}-21 \\
(0.6)\end{array}$ & $\begin{array}{c}.34 \\
(2.8)\end{array}$ & $\begin{array}{l}12.9 \\
(2.0)\end{array}$ & $\begin{array}{c}.80 \\
(1.2)\end{array}$ & .33 & 47 \\
\hline 13 & $\begin{array}{r}-274 \\
(1.0)\end{array}$ & $\begin{array}{l}3.51 \\
(3.4)\end{array}$ & $\begin{array}{c}142.3 \\
(3.0)\end{array}$ & $\begin{array}{l}1.64 \\
(3.0)\end{array}$ & .65 & 48 \\
\hline 14 & $\begin{array}{l}-51 \\
\text { (1.4) }\end{array}$ & $\begin{array}{c}.57 \\
(4.4)\end{array}$ & $\begin{array}{l}29.3 \\
(4.6)\end{array}$ & $\begin{array}{c}.43 \\
(2.8)\end{array}$ & .70 & 48 \\
\hline 15 & $\begin{array}{l}-81 \\
(2.0)\end{array}$ & $\begin{array}{c}.37 \\
(2.7)\end{array}$ & $\begin{array}{l}31.4 \\
(4.5)\end{array}$ & $\begin{array}{c}.21 \\
(1.2)\end{array}$ & .52 & 48 \\
\hline 16 & $\begin{array}{l}-60 \\
(2.0)\end{array}$ & $\begin{array}{c}.00 \\
(0.0)\end{array}$ & $\begin{array}{l}23.9 \\
(4.7)\end{array}$ & $\begin{array}{l}1.21 \\
(3.1)\end{array}$ & .56 & 48 \\
\hline 17 & $\begin{array}{c}-239 \\
(1.3)\end{array}$ & $\begin{array}{l}1.48 \\
(2.3)\end{array}$ & $\begin{array}{c}145.9 \\
(4.7)\end{array}$ & $\begin{array}{c}10.73 \\
(3.3)\end{array}$ & .62 & 48 \\
\hline 18 & $\begin{array}{r}-251 \\
(2.4)\end{array}$ & $\begin{array}{l}2.95 \\
(7.4)\end{array}$ & $\begin{array}{l}65.8 \\
(3.7)\end{array}$ & $\begin{array}{l}3.90 \\
(2.7)\end{array}$ & .81 & 48 \\
\hline 19 & $\begin{array}{r}-144 \\
(1.6)\end{array}$ & $\begin{array}{c}.01 \\
(0.0)\end{array}$ & $\begin{array}{l}91.2 \\
(6.0)\end{array}$ & $\begin{array}{c}.90 \\
(4.2)\end{array}$ & .65 & 48 \\
\hline 20 & & & NA & & & \\
\hline
\end{tabular}


Table 9.A.11 (continued)

\begin{tabular}{|c|c|c|c|c|c|c|}
\hline \multirow[b]{2}{*}{$\begin{array}{l}\text { Industry } \\
\text { No. }\end{array}$} & \multirow[b]{2}{*}{$\begin{array}{l}\text { Intercept } \\
\text { (\$ millions) }\end{array}$} & \multicolumn{3}{|c|}{ Coefficients of } & \multirow[b]{2}{*}{$\bar{R}^{2}$} & \multirow[b]{2}{*}{$\begin{array}{c}\text { No. of } \\
\text { Obs. }\end{array}$} \\
\hline & & GDP & $\begin{array}{c}\text { GDP per } \\
\text { Capita } \\
\text { (GDPC) }\end{array}$ & $\begin{array}{c}\text { Net } \\
\text { Local } \\
\text { Sales } \\
\text { (NLS) }\end{array}$ & & \\
\hline 21 & $\begin{array}{c}-12 \\
(0.2)\end{array}$ & $\begin{array}{c}.19 \\
(1.0)\end{array}$ & $\begin{array}{l}37.6 \\
(4.3)\end{array}$ & $\begin{array}{c}.41 \\
(1.8)\end{array}$ & .44 & 48 \\
\hline 22 & $\begin{array}{c}-4 \\
(0.0)\end{array}$ & $\begin{array}{r}-1.20 \\
(5.8)\end{array}$ & $\begin{array}{l}34.2 \\
(5.2)\end{array}$ & $\begin{array}{c}1.06 \\
(13.6)\end{array}$ & .90 & 48 \\
\hline 23 & $\begin{array}{l}-32 \\
(0.2)\end{array}$ & $\begin{array}{l}1.13 \\
(1.8)\end{array}$ & $\begin{array}{r}135.4 \\
(4.7)\end{array}$ & $\begin{array}{l}2.77 \\
(4.4)\end{array}$ & .69 & 48 \\
\hline 24 & $\begin{array}{c}-58 \\
(1.8)\end{array}$ & $\begin{array}{l}.17 \\
(1.6)\end{array}$ & $\begin{array}{l}26.9 \\
(4.9)\end{array}$ & $\begin{array}{l}2.29 \\
(5.0)\end{array}$ & .65 & 48 \\
\hline 25 & $\begin{array}{l}-52 \\
(0.5)\end{array}$ & $\begin{array}{c}.64 \\
(2.0)\end{array}$ & $\begin{array}{l}51.3 \\
(3.0)\end{array}$ & $\begin{array}{l}1.02 \\
(3.7)\end{array}$ & .56 & 48 \\
\hline 26 & $\begin{array}{c}30 \\
(0.5)\end{array}$ & $\begin{array}{c}-.43 \\
(1.4)\end{array}$ & $\begin{array}{l}20.7 \\
(2.3)\end{array}$ & $\begin{array}{l}2.43 \\
(4.8)\end{array}$ & .59 & 48 \\
\hline 27 & $\begin{array}{r}-122 \\
(1.3)\end{array}$ & $\begin{array}{c}.87 \\
(2.6)\end{array}$ & $\begin{array}{l}83.8 \\
(5.2)\end{array}$ & $\begin{array}{l}1.51 \\
(2.4)\end{array}$ & .62 & 48 \\
\hline 28 & $\begin{array}{c}-441 \\
(1.3)\end{array}$ & $\begin{array}{l}1.93 \\
(1.6)\end{array}$ & $\begin{array}{r}243.1 \\
(4.1)\end{array}$ & $\begin{array}{c}.63 \\
(3.5)\end{array}$ & .55 & 48 \\
\hline 29 & & & NA & & & \\
\hline 30 & $\begin{array}{r}-284 \\
(3.3)\end{array}$ & $\begin{array}{c}3.23 \\
(10.8)\end{array}$ & $\begin{array}{l}69.1 \\
(4.8)\end{array}$ & $\begin{array}{l}1.62 \\
(0.7)\end{array}$ & .85 & 48 \\
\hline 31 & $\begin{array}{l}-28 \\
(1.5)\end{array}$ & $\begin{array}{c}.09 \\
(1.3)\end{array}$ & $\begin{array}{l}16.1 \\
(5.0)\end{array}$ & $\begin{array}{l}1.45 \\
(5.7)\end{array}$ & .72 & 48 \\
\hline 32 & $\begin{array}{l}-57 \\
(1.1)\end{array}$ & $\begin{array}{c}-.08 \\
(0.4)\end{array}$ & $\begin{array}{l}37.7 \\
(4.2)\end{array}$ & $\begin{array}{l}2.57 \\
(3.8)\end{array}$ & .54 & 48 \\
\hline 33 & $\begin{array}{l}-95 \\
(1.2)\end{array}$ & $\begin{array}{c}.49 \\
(1.7)\end{array}$ & $\begin{array}{l}67.0 \\
(4.9)\end{array}$ & $\begin{array}{l}1.57 \\
(7.9)\end{array}$ & .81 & 48 \\
\hline 34 & $\begin{array}{c}-217 \\
(1.8)\end{array}$ & $\begin{array}{c}.26 \\
(0.6)\end{array}$ & $\begin{array}{l}94.9 \\
(4.5)\end{array}$ & $\begin{array}{l}5.56 \\
(3.5)\end{array}$ & .56 & 48 \\
\hline
\end{tabular}

Notes: For definitions and industry list, see Table 9.A.5. Numbers in parentheses are tstatistics. 
Table 9.A.12 OLS Equations for Non-U.S. Exports Based on Net Local Sales and Net Export Sales by Majority-Owned U.S. Affiliates, 1982 (30 industries)

\begin{tabular}{|c|c|c|c|c|c|c|c|}
\hline \multirow[b]{2}{*}{$\begin{array}{l}\text { Industry } \\
\text { No. }\end{array}$} & \multirow[b]{2}{*}{$\begin{array}{l}\text { Intercept } \\
\text { (\$ millions) }\end{array}$} & \multicolumn{4}{|c|}{ Coefficients of } & \multirow[b]{2}{*}{$\bar{R}^{2}$} & \multirow[b]{2}{*}{$\begin{array}{c}\text { No. of } \\
\text { Obs. }\end{array}$} \\
\hline & & GDP & $\begin{array}{c}\text { GDP } \\
\text { per } \\
\text { Capita } \\
\text { (GDPC) }\end{array}$ & $\begin{array}{c}\text { Net } \\
\text { Local } \\
\text { Sales } \\
\text { (NLS) }\end{array}$ & $\begin{array}{c}\text { Net } \\
\text { Export } \\
\text { Sales } \\
\text { (NXS) }\end{array}$ & & \\
\hline 1 & $\begin{array}{l}-11 \\
(0.5)\end{array}$ & $\begin{array}{c}.07 \\
(0.8)\end{array}$ & $\begin{array}{l}14.2 \\
(3.5)\end{array}$ & $\begin{array}{c}.07 \\
(1.6)\end{array}$ & $\begin{array}{c}.64 \\
(1.8)\end{array}$ & .50 & 48 \\
\hline 2 & $\begin{array}{l}-64 \\
(2.0)\end{array}$ & $\begin{array}{c}.51 \\
(3.4)\end{array}$ & $\begin{array}{l}16.9 \\
(3.0)\end{array}$ & $\begin{array}{l}.15 \\
(0.7)\end{array}$ & $\begin{array}{l}1.69 \\
(4.3)\end{array}$ & .71 & 47 \\
\hline 3 & $\begin{array}{l}-18 \\
(0.8)\end{array}$ & $\begin{array}{c}.18 \\
(2.7)\end{array}$ & $\begin{array}{c}5.8 \\
(1.6)\end{array}$ & $\begin{array}{c}-.08 \\
(0.7)\end{array}$ & $\begin{array}{l}.38 \\
(1.8)\end{array}$ & .30 & 43 \\
\hline 4 & $\begin{array}{c}-528 \\
(1.8)\end{array}$ & $\begin{array}{l}7.08 \\
(6.94)\end{array}$ & $\begin{array}{c}123.5 \\
(2.4)\end{array}$ & $\begin{array}{l}1.15 \\
(2.0)\end{array}$ & $\begin{array}{l}2.92 \\
(2.0)\end{array}$ & .77 & 48 \\
\hline 5 & $\begin{array}{c}-599 \\
(1.8)\end{array}$ & $\begin{array}{l}4.03 \\
(3.4)\end{array}$ & $\begin{array}{c}185.1 \\
(3.1)\end{array}$ & $\begin{array}{l}9.10 \\
(1.8)\end{array}$ & $\begin{array}{l}7.53 \\
(2.4)\end{array}$ & .62 & 48 \\
\hline 6 & \multicolumn{7}{|c|}{ NA } \\
\hline 7 & \multicolumn{7}{|c|}{ NA } \\
\hline 8 & $\begin{array}{l}-21 \\
(1.4)\end{array}$ & $\begin{array}{l}.099 \\
(1.8)\end{array}$ & $\begin{array}{c}9.8 \\
(3.6)\end{array}$ & $\begin{array}{c}-.07 \\
(0.8)\end{array}$ & $\begin{array}{l}3.52 \\
(7.3)\end{array}$ & .74 & 48 \\
\hline 9 & $\begin{array}{l}-35 \\
(1.3)\end{array}$ & $\begin{array}{l}.102 \\
(1.1)\end{array}$ & $\begin{array}{l}19.5 \\
(4.1)\end{array}$ & $\begin{array}{c}.96 \\
(1.8)\end{array}$ & $\begin{array}{c}.21 \\
(0.1)\end{array}$ & .56 & 48 \\
\hline 10 & $\begin{array}{l}-34 \\
(1.4)\end{array}$ & $\begin{array}{c}.63 \\
(4.6)\end{array}$ & $\begin{array}{l}21.8 \\
(5.2)\end{array}$ & $\begin{array}{c}-.00 \\
(0.0)\end{array}$ & $\begin{array}{c}.34 \\
(2.4)\end{array}$ & .81 & 48 \\
\hline 11 & $\begin{array}{c}-18 \\
(1.8)\end{array}$ & $\begin{array}{l}.084 \\
(1.8)\end{array}$ & $\begin{array}{l}12.0 \\
(7.0)\end{array}$ & $\begin{array}{r}-.077 \\
(1.8)\end{array}$ & $\begin{array}{l}1.15 \\
(9.2)\end{array}$ & .87 & 48 \\
\hline 12 & $\begin{array}{l}-12 \\
(0.3)\end{array}$ & $\begin{array}{c}.34 \\
(2.9)\end{array}$ & $\begin{array}{c}8.5 \\
(1.3)\end{array}$ & $\begin{array}{l}.245 \\
(0.3)\end{array}$ & $\begin{array}{l}3.02 \\
(2.1)\end{array}$ & .39 & 47 \\
\hline 13 & $\begin{array}{c}-133 \\
(0.6)\end{array}$ & $\begin{array}{l}4.07 \\
(4.5)\end{array}$ & $\begin{array}{l}86.9 \\
(2.0)\end{array}$ & $\begin{array}{r}.569 \\
(1.1)\end{array}$ & $\begin{array}{l}1.46 \\
(4.0)\end{array}$ & .74 & 48 \\
\hline 14 & $\begin{array}{l}-39 \\
(1.1)\end{array}$ & $\begin{array}{c}.62 \\
(5.2)\end{array}$ & $\begin{array}{l}24.9 \\
(4.1)\end{array}$ & $\begin{array}{r}-.041 \\
(0.2)\end{array}$ & $\begin{array}{c}.99 \\
(3.2)\end{array}$ & .75 & 48 \\
\hline 15 & $\begin{array}{l}-54 \\
(1.5)\end{array}$ & $\begin{array}{c}.27 \\
(2.2)\end{array}$ & $\begin{array}{l}24.8 \\
(4.0)\end{array}$ & $\begin{array}{r}.018 \\
(0.1)\end{array}$ & $\begin{array}{l}2.20 \\
(4.1)\end{array}$ & .65 & 48 \\
\hline 16 & $\begin{array}{l}-50 \\
(2.3)\end{array}$ & $\begin{array}{c}.02 \\
(0.2)\end{array}$ & $\begin{array}{l}17.4 \\
(4.5)\end{array}$ & $\begin{array}{c}.84 \\
(2.9)\end{array}$ & $\begin{array}{l}1.99 \\
(6.2)\end{array}$ & .76 & 48 \\
\hline 17 & $\begin{array}{r}-210 \\
(1.1)\end{array}$ & $\begin{array}{l}1.46 \\
(2.2)\end{array}$ & $\begin{array}{r}137.8 \\
(4.1)\end{array}$ & $\begin{array}{l}9.29 \\
(2.4)\end{array}$ & $\begin{array}{l}9.42 \\
(0.7)\end{array}$ & .61 & 48 \\
\hline 18 & $\begin{array}{r}-204 \\
(2.5)\end{array}$ & $\begin{array}{l}2.96 \\
(9.6)\end{array}$ & $\begin{array}{l}51.4 \\
(3.6)\end{array}$ & $\begin{array}{c}-.36 \\
(0.3)\end{array}$ & $\begin{array}{c}11.13 \\
(5.4)\end{array}$ & .89 & 48 \\
\hline 19 & $\begin{array}{r}-111 \\
(1.2)\end{array}$ & $\begin{array}{c}.03 \\
(0.1)\end{array}$ & $\begin{array}{l}85.3 \\
(5.6)\end{array}$ & $\begin{array}{r}.210 \\
(0.5)\end{array}$ & $\begin{array}{l}1.95 \\
(1.8)\end{array}$ & .67 & 48 \\
\hline 20 & \multicolumn{7}{|c|}{ NA } \\
\hline
\end{tabular}


Table 9.A.12 (continued)

\begin{tabular}{|c|c|c|c|c|c|c|c|}
\hline \multirow[b]{2}{*}{$\begin{array}{l}\text { Industry } \\
\text { No. }\end{array}$} & \multirow[b]{2}{*}{$\begin{array}{l}\text { Intercept } \\
(\$ \text { millions })\end{array}$} & \multicolumn{4}{|c|}{ Coefficients of } & \multirow[b]{2}{*}{$\bar{R}^{2}$} & \multirow[b]{2}{*}{$\begin{array}{l}\text { No. of } \\
\text { Obs. }\end{array}$} \\
\hline & & GDP & $\begin{array}{c}\text { GDP } \\
\text { per } \\
\text { Capita } \\
\text { (GDPC) }\end{array}$ & $\begin{array}{c}\text { Net } \\
\text { Local } \\
\text { Sales } \\
\text { (NLS) }\end{array}$ & $\begin{array}{c}\text { Net } \\
\text { Export } \\
\text { Sales } \\
\text { (NXS) }\end{array}$ & & \\
\hline 21 & $\begin{array}{c}17 \\
(0.4)\end{array}$ & $\begin{array}{c}.10 \\
(0.6)\end{array}$ & $\begin{array}{l}29.5 \\
(3.8)\end{array}$ & $\begin{array}{c}-.01 \\
(0.0)\end{array}$ & $\begin{array}{c}.93 \\
(4.1)\end{array}$ & .59 & 48 \\
\hline 22 & $\begin{array}{c}1 \\
(0.0)\end{array}$ & $\begin{array}{r}-1.07 \\
(4.5)\end{array}$ & $\begin{array}{l}33.1 \\
(5.0)\end{array}$ & $\begin{array}{c}.88 \\
(5.2)\end{array}$ & $\begin{array}{c}.22 \\
(1.2)\end{array}$ & .90 & 48 \\
\hline 23 & $\begin{array}{c}38 \\
(0.2)\end{array}$ & $\begin{array}{l}1.59 \\
(2.6)\end{array}$ & $\begin{array}{l}111.0 \\
(3.92)\end{array}$ & $\begin{array}{r}-.67 \\
(0.5)\end{array}$ & $\begin{array}{l}4.37 \\
(2.8)\end{array}$ & .73 & 48 \\
\hline 24 & $\begin{array}{l}-50 \\
(1.7)\end{array}$ & $\begin{array}{c}.08 \\
(0.8)\end{array}$ & $\begin{array}{c}24.6 \\
(4.8)\end{array}$ & $\begin{array}{l}2.02 \\
(4.6)\end{array}$ & $\begin{array}{c}1.72 \\
(3.0)\end{array}$ & .71 & 48 \\
\hline 25 & $\begin{array}{l}-56 \\
(0.6)\end{array}$ & $\begin{array}{c}.65 \\
(2.0)\end{array}$ & $\begin{array}{l}51.4 \\
(3.1)\end{array}$ & $\begin{array}{c}.25 \\
(0.3)\end{array}$ & $\begin{array}{l}1.98 \\
(1.1)\end{array}$ & .56 & 48 \\
\hline 26 & $\begin{array}{l}-39 \\
(1.3)\end{array}$ & $\begin{array}{c}.35 \\
(1.9)\end{array}$ & $\begin{array}{l}14.2 \\
(2.9)\end{array}$ & $\begin{array}{c}.42 \\
(1.2)\end{array}$ & $\begin{array}{l}1.85 \\
(10.0)\end{array}$ & .88 & 48 \\
\hline 27 & $\begin{array}{l}-81 \\
(0.9)\end{array}$ & $\begin{array}{c}.83 \\
(2.7)\end{array}$ & $\begin{array}{l}67.7 \\
(4.3)\end{array}$ & $\begin{array}{c}.45 \\
(0.7)\end{array}$ & $\begin{array}{c}4.45 \\
(3.0)\end{array}$ & .70 & 48 \\
\hline 28 & $\begin{array}{r}-408 \\
(1.1)\end{array}$ & $\begin{array}{l}1.77 \\
(1.4)\end{array}$ & $\begin{array}{r}241.0 \\
(4.0)\end{array}$ & $\begin{array}{l}.52 \\
(2.1)\end{array}$ & $\begin{array}{c}.23 \\
(0.8)\end{array}$ & .55 & 48 \\
\hline 29 & \multicolumn{7}{|c|}{ NA } \\
\hline 30 & $\begin{array}{c}-251 \\
(3.0)\end{array}$ & $\begin{array}{r}3.34 \\
(11.2)\end{array}$ & $\begin{array}{l}64.1 \\
(4.5)\end{array}$ & $\begin{array}{l}4.66 \\
(1.7)\end{array}$ & $\begin{array}{r}-15.71 \\
(1.9)\end{array}$ & .86 & 48 \\
\hline 31 & $\begin{array}{r}-19.4 \\
(1.2)\end{array}$ & $\begin{array}{c}.07 \\
(1.2)\end{array}$ & $\begin{array}{l}13.5 \\
(4.7)\end{array}$ & $\begin{array}{l}1.05 \\
(4.3)\end{array}$ & $\begin{array}{l}1.43 \\
(3.8)\end{array}$ & .78 & 48 \\
\hline 32 & $\begin{array}{l}-54 \\
(1.0)\end{array}$ & $\begin{array}{c}-.05 \\
(0.2)\end{array}$ & $\begin{array}{l}36.1 \\
(3.8)\end{array}$ & $\begin{array}{l}2.23 \\
(2.4)\end{array}$ & $\begin{array}{l}1.06 \\
(0.6)\end{array}$ & .53 & 48 \\
\hline 33 & $\begin{array}{l}-92 \\
(1.2)\end{array}$ & $\begin{array}{c}.31 \\
(1.0)\end{array}$ & $\begin{array}{l}69.3 \\
(5.1)\end{array}$ & $\begin{array}{l}2.18 \\
(5.0)\end{array}$ & $\begin{array}{c}-.68 \\
(1.6)\end{array}$ & .81 & 48 \\
\hline 34 & $\begin{array}{c}-211 \\
(1.7)\end{array}$ & $\begin{array}{c}.18 \\
(0.4)\end{array}$ & $\begin{array}{l}92.7 \\
(4.2)\end{array}$ & $\begin{array}{l}5.30 \\
(3.2)\end{array}$ & $\begin{array}{l}1.90 \\
(0.5)\end{array}$ & .55 & 48 \\
\hline
\end{tabular}

Notes: For definitions and industry list, see Table 9.A.5. Numbers in parentheses are tstatistics. 


\begin{tabular}{|c|c|c|c|c|c|c|c|c|c|}
\hline \multirow[b]{3}{*}{$\begin{array}{l}\text { Industry } \\
\text { Group }\end{array}$} & \multirow[b]{3}{*}{ Intercept } & \multicolumn{6}{|c|}{ Coefficients of } & \multirow[b]{3}{*}{$\bar{R}^{2}$} & \multirow[b]{3}{*}{$\begin{array}{c}\text { No. of } \\
\text { Obs. }\end{array}$} \\
\hline & & & & \multicolumn{3}{|c|}{ Majority-Owned Affiliate } & \multirow[b]{2}{*}{$\begin{array}{l}\text { Minority- } \\
\text { Owned } \\
\text { Affiliate } \\
\text { Net Sales } \\
\text { (MONS) }\end{array}$} & & \\
\hline & & GDP & $\begin{array}{c}\text { GDP } \\
\text { per } \\
\text { Capita } \\
\text { (GDPC) }\end{array}$ & $\begin{array}{l}\text { Net } \\
\text { Sales } \\
\text { (NS) }\end{array}$ & $\begin{array}{c}\text { Net } \\
\text { Local } \\
\text { Sales } \\
\text { (NLS) }\end{array}$ & $\begin{array}{c}\text { Net } \\
\text { Export } \\
\text { Sales } \\
\text { (NXS) }\end{array}$ & & & \\
\hline A & $\begin{array}{r}-1,289 \\
(2.14)\end{array}$ & $\begin{array}{c}8.96 \\
(3.76)\end{array}$ & $\begin{array}{r}353.7 \\
(3.0)\end{array}$ & $\begin{array}{l}584.8 \\
(1.66)\end{array}$ & & & $\begin{array}{r}-2,194 \\
(1.85)\end{array}$ & .80 & 22 \\
\hline $\mathbf{B}$ & $\begin{array}{r}-1,055 \\
(2.41)\end{array}$ & $\begin{array}{l}11.75 \\
(5.33)\end{array}$ & $\begin{array}{l}511.5 \\
(2.80)\end{array}$ & $\begin{array}{l}254.6 \\
(3.54)\end{array}$ & & & $\begin{array}{r}-2,446 \\
(4.65)\end{array}$ & .87 & 27 \\
\hline $\mathrm{C}$ & $\begin{array}{r}-810.4 \\
(1.07)\end{array}$ & $\begin{array}{c}5.20 \\
(2.70)\end{array}$ & $\begin{array}{l}323.3 \\
(2.98)\end{array}$ & $\begin{array}{r}2,278.8 \\
(4.14)\end{array}$ & & & $\begin{array}{r}-2,252 \\
(1.63)\end{array}$ & .81 & 18 \\
\hline D & $\begin{array}{c}52.4 \\
(0.14)\end{array}$ & $\begin{array}{c}2.68 \\
(1.06)\end{array}$ & $\begin{array}{l}181.4 \\
(3.33)\end{array}$ & $\begin{array}{l}592.6 \\
(1.97)\end{array}$ & & & $\begin{array}{l}1,152 \\
(0.92)\end{array}$ & .88 & 24 \\
\hline$E$ & $\begin{array}{r}-255.1 \\
(0.70)\end{array}$ & $\begin{array}{l}-.08 \\
(0.07)\end{array}$ & $\begin{array}{l}151.7 \\
(2.52)\end{array}$ & $\begin{array}{r}2,042.7 \\
(6.72)\end{array}$ & & & $\begin{array}{l}-158 \\
(0.22)\end{array}$ & .80 & 24 \\
\hline $\mathbf{F}$ & $\begin{array}{r}-547.7 \\
(0.92)\end{array}$ & $\begin{array}{c}7.59 \\
(2.51)\end{array}$ & $\begin{array}{l}215.7 \\
(2.57)\end{array}$ & $\begin{array}{l}511.8 \\
(2.94)\end{array}$ & & & $\begin{array}{l}-641 \\
(2.69)\end{array}$ & .85 & 19 \\
\hline $\mathbf{B}$ & $\begin{array}{r}-2,034 \\
(3.27)\end{array}$ & $\begin{array}{l}11.27 \\
(3.45)\end{array}$ & $\begin{array}{l}615.4 \\
(5.22)\end{array}$ & & $\begin{array}{l}170.9 \\
(0.43)\end{array}$ & & $\begin{array}{r}-2,627 \\
(3.95)\end{array}$ & .89 & 17 \\
\hline
\end{tabular}




\begin{tabular}{|c|c|c|c|c|c|c|c|c|c|}
\hline \multirow[b]{3}{*}{$\begin{array}{l}\text { Industry } \\
\text { Group }\end{array}$} & \multirow[b]{3}{*}{ Intercept } & \multicolumn{6}{|c|}{ Coefficients of } & \multirow[b]{3}{*}{$\bar{R}^{2}$} & \multirow[b]{3}{*}{$\begin{array}{l}\text { No. of } \\
\text { Obs. }\end{array}$} \\
\hline & & & & \multicolumn{3}{|c|}{ Majority-Owned Affiliate } & \multirow[b]{2}{*}{$\begin{array}{l}\text { Minority- } \\
\text { Owned } \\
\text { Affiliate } \\
\text { Net Sales } \\
\text { (MONS) }\end{array}$} & & \\
\hline & & GDP & $\begin{array}{c}\text { GDP } \\
\text { per } \\
\text { Capita } \\
\text { (GDPC) }\end{array}$ & $\begin{array}{c}\text { Net } \\
\text { Sales } \\
\text { (NS) }\end{array}$ & $\begin{array}{l}\text { Net } \\
\text { Local } \\
\text { Sales } \\
\text { (NLS) }\end{array}$ & $\begin{array}{c}\text { Net } \\
\text { Export } \\
\text { Sales } \\
\text { (NXS) }\end{array}$ & & & \\
\hline $\mathbf{D}$ & $\begin{array}{r}-201.3 \\
(0.48)\end{array}$ & $\begin{array}{c}5.93 \\
(1.58)\end{array}$ & $\begin{array}{l}211.6 \\
(3.50)\end{array}$ & & $\begin{array}{l}148.8 \\
(0.20)\end{array}$ & & $\begin{array}{l}2,282 \\
(1.61)\end{array}$ & .86 & 22 \\
\hline $\mathbf{E}$ & $\begin{array}{r}-208.5 \\
(0.44)\end{array}$ & $\begin{array}{l}-.57 \\
(0.41)\end{array}$ & $\begin{array}{l}215.1 \\
(2.62)\end{array}$ & & $\begin{array}{r}3,160.4 \\
(5.20)\end{array}$ & & $\begin{array}{l}-843 \\
(0.95)\end{array}$ & .78 & 18 \\
\hline $\mathrm{F}$ & $\begin{array}{r}-398.0 \\
(2.59)\end{array}$ & $\begin{array}{l}13.13 \\
(17.1)\end{array}$ & $\begin{array}{l}139.2 \\
(6.26)\end{array}$ & & $\begin{array}{l}591.4 \\
(8.16)\end{array}$ & & $\begin{array}{r}-1,030 \\
(17.19)\end{array}$ & .99 & 17 \\
\hline $\mathbf{B}$ & $\begin{array}{r}-1,230.5 \\
(2.22)\end{array}$ & $\begin{array}{l}13.26 \\
(5.02)\end{array}$ & $\begin{array}{l}353.8 \\
(2.8 \mathrm{I})\end{array}$ & & $\begin{array}{r}-270.2 \\
(0.79)\end{array}$ & $\begin{array}{r}1,140.9 \\
(3.04)\end{array}$ & $\begin{array}{r}-2,616 \\
(5.03)\end{array}$ & .93 & 17 \\
\hline $\mathbf{D}$ & $\begin{array}{c}35.0 \\
(0.12)\end{array}$ & $\begin{array}{c}7.97 \\
(3.11)\end{array}$ & $\begin{array}{l}123.6 \\
(2.77)\end{array}$ & & $\begin{array}{r}-1,665.3 \\
(2.67)\end{array}$ & $\begin{array}{r}2,355.2 \\
(4.76)\end{array}$ & $\begin{array}{l}1,304 \\
(1.34)\end{array}$ & .94 & 22 \\
\hline $\mathbf{E}$ & $\begin{array}{r}-463.1 \\
(1.14)\end{array}$ & $\begin{array}{l}-.29 \\
(0.25)\end{array}$ & $\begin{array}{l}214.0 \\
(3.13)\end{array}$ & & $\begin{array}{r}1,211.2 \\
(1.37)\end{array}$ & $\begin{array}{r}3,407.5 \\
(2.69)\end{array}$ & $\begin{array}{c}-.6 \\
(0.01)\end{array}$ & .89 & 18 \\
\hline $\mathbf{F}$ & $\begin{array}{r}-393.2 \\
(2.41)\end{array}$ & $\begin{array}{c}13.07 \\
(14.75)\end{array}$ & $\begin{array}{l}139.1 \\
(6.01)\end{array}$ & & $\begin{array}{l}585.7 \\
(7.00)\end{array}$ & $\begin{array}{c}15.4 \\
(0.16)\end{array}$ & $\begin{array}{r}-1,025 \\
(15.0)\end{array}$ & .99 & 17 \\
\hline
\end{tabular}

Notes: See Table 9.A.8. 


\section{References}

Bergsten, C. Fred, Thomas Horst, and Theodore H. Moran. 1978. American multinationals and American interests. Washington, D.C.: Brookings Institution.

Chenery, Hollis B. 1960. Patterns of industrial 'growth. American Economic Review 50 (September): 624-54.

Kravis, Irving B., and Robert E. Lipsey. 1984. The diffusion of economic growth in the world economy. In John W. Kendrick, ed., International comparisons of productivity and causes of the slowdown. Cambridge, Mass.: Ballinger for the American Enterprise Institute.

Leamer, Edward E., and Robert M. Stern. 1970. Quantitative international economics. Boston: Allyn and Bacon.

Linneman, Hans. 1966. An econometric study of trade flows. Amsterdam: North-Holland.

Lipsey, Robert E., and Merle Yahr Weiss. 1981. Foreign production and exports in manufacturing industries. Review of Economics and Statistics 63:488-94.

- 1984. Foreign production and exports of individual firms. Review of Economics and Statistics 66:304-8.

Swedenborg, Birgitta. 1979. The multinational operations of Swedish firms. Stockholm: Industriens Utredningsinstitut.

- 1982. Svensk industri i utlandet. Stockholm: Industriens Utredningsinstitut.

United Nations and Commission of the European Communities. 1986. World comparisons of purchasing power and real product for 1980. Phase IV of the International Comparison Project: Part One: Summary Results for 60 Countries. New York: United Nations and Eurostat.

U.S. Department of Commerce. 1985. U.S. direct investment abroad: 1982 benchmark survey data. Bureau of Economic Analysis.

\section{Comment Steven J. Matusz}

Does foreign direct investment substitute for exports, or is such investment complementary to exports? This is the question addressed by the authors. Using U.S. and Swedish data, they find that the preponderance of the evidence suggests that the relationship between direct foreign investment and export sales is one of complementarity. While they find some limited evidence of substitutability in the U.S. data, they find no evidence of substitutability in the Swedish data.

The following discussion focuses on two distinctly different issues, although both issues lead to the same general result. In particular, I argue that we should not be surprised that the preponderance of the evidence points toward complementarity. The first issue deals with the

Steven J. Matusz is assistant professor of economics at Michigan State University. 
relationships mandated by the balance of payments under a regime of flexible exchange rates. The second relates to the distinction between the decision to invest and the decision to produce a given amount of output.

Concerning the balance of payments, we know that in a world of flexible exchange rates, the current account balance must exactly offset capital flows. An increase in foreign direct investment, all other things equal, will reduce the surplus or increase the deficit on the capital account. In turn, the exchange rate will adjust to induce an opposite change in the current account. Ignoring changes in unilateral transfers and returns to past investments, such a change implies either an increase in exports or a reduction in imports. While particular investment projects may change the relative composition of a bundle of exports, increasing exports of some products and reducing exports of others, the overall result must be an increase in net exports. This accounting identity suggests that in an industry-by-industry study such as the one undertaken by the authors, we should find a preponderance of evidence suggesting a positive relationship between current direct foreign investment and net exports, although there may be a few industries where the relationship is negative.

In at least two respects, the relationships necessitated by the balance of payments are not precisely the relationships that were tested by the authors, and therefore the a priori arguments in favor of finding complementarity are weakened. First, the authors use net sales of foreign affiliates to proxy for foreign direct investment. To the extent that such sales reflect past investment decisions, one might argue that these past investments can influence today's current account in a negative direction. However, one would have to argue that a high capital outflow in all previous periods leads to a low capital outflow in the present period, since it is the present capital account that is linked to the present current account. Second, the dependent variable is gross exports. Clearly, gross exports may decline even as net exports increase.

Regardless of the aggregate impact of direct foreign investment, the differential impact across industries is ambiguous. As the authors argue, most of the theory relating to the motive for direct foreign investment takes the size of the foreign market as given. Typically, one asks why a firm would choose to invest abroad rather than licensing a foreign agent or exporting the product. The very phrasing of the question implies that production abroad substitutes for exports. On the other hand, the authors correctly assert that theoretical arguments can be made to show that direct foreign investment and exports are complementary. For example, if the foreign affiliate is mostly a final assembly plant that imports the components from the parent, it follows 
that an increase in the activity of the foreign affiliate will stimulate exports from the parent. Alternatively, one might argue in favor of a microeconomic version of Say's law, that the foreign demand for a particular product is parameterized on the level of production undertaken in the foreign country.

Once the foreign affiliate is in operation, an increase in foreign demand can be expected to lead to an increase in production by the foreign affiliate as well as an increase in exports. If foreign demand is parameterized on the level of sales of the affiliate, any increase in demand initiated by, say, an increase in income will be magnified because the increased local production will stimulate further increases in demand. After controlling for other factors that might influence demand and holding all other things equal, we would expect to find a nonnegative coefficient on net sales of the foreign affiliate when trying to explain exports.

On the other hand, if the initial increase in the sales of the affiliate was due to a reduction in production costs abroad relative to those of the parent, we would see a substitution of affiliate sales for exports unless the added affiliate sales stimulate foreign demand so much that the substitution effect is swamped. It would seem that this is what is being tested in the cross-sectional study. In the cross section, investment is put in place and controls have been incorporated to account for variations in demand. Unobserved variations in production costs across countries induce firms to alter their mix of parent and affiliate production. In most of the results presented, it appears that the effect of affiliate sales on foreign demand outweighs the substitution effect due to relative cost differences.

Both of the above situations take as given the existence of the foreign affiliate, but if we wish to examine the relationship between direct foreign investment and exports, we must ask how the very existence of the affiliate influences the level of exports. In particular, if that affiliate did not exist, would the parent have expanded U.S. plant capacity and therefore production? Perhaps one way to address this question might be to separately estimate the elasticity of exports with respect to domestic investment, and the direct effect of foreign production on the size of the market. With such estimates in hand, it might then be possible to simulate the effect of an extra billion dollars of investment if undertaken at home and then if undertaken abroad. The difference in simulated export levels might then be a nearer approximation of the effect of direct foreign investment on exports for a given industry. 


\section{Comment John Mutti}

This chapter revisits a topic debated extensively in the 1970s. Such a reexamination allows new data and different analytical tools to be applied in evaluating the way foreign affiliate production affects a country's export performance. However, the policy context motivating such a reexamination differs from that of the 1960 s and 1970 s, when much of the attention focused on macroeconomic concerns in a world of fixed exchange rates. Fears of lost output in the United States and the potential exportation of jobs led to several legislative proposals to restrict foreign investment by U.S. firms. While those concerns may have been misdirected then, they seem even less relevant now that the United States is a large net importer of capital in a world of flexible exchange rates. The relationship between foreign investment and export performance does have a continued policy relevance today, given the role of direct foreign investment in current multilateral trade talks. In particular, would reduced barriers to foreign investment result in greater demand for U.S. exports and a consequent improvement in the terms of trade?

Chapter 9, by Blomström, Lipsey, and Kulchycky, presents estimates of the relationship between direct investment in one country by residents of another and the level of exports from the latter country to the former, based on Swedish and U.S. data. Two approaches are utilized, one based on cross-sectional data to explain the level of exports for a single year (1978 for Sweden and 1982 for the United States) and the other designed to explain the change in exports between two years (1970 and 1978 for Sweden). The underlying analytical framework is the gravity model of trade, which is modified to explain one country's exports to another as a function of economic activity in the recipient country, cost-related factors (distance, trade barriers, factor endowments), and production in the recipient country of affiliates controlled by the home country. The authors omit any of the cost-related variables. Omitted variables result in biased estimates of the remaining coefficients, but the direction of bias need not necessarily result in misleading inferences being drawn from the authors' work. For example, omitting the tariff variable could result in a downward bias in the estimated coefficient for affiliate sales. A tariff would be expected to reduce exports received and also to give an incentive for greater foreign affiliate production behind the tariff wall; thus, when the tariff is omitted, the estimated coefficient for affiliate sales may be smaller because it 
reflects some of the negative influence of the tariff. In the absence of simultaneity bias, where affiliate sales are correlated with the error term in the export equation, a finding of complementarity would not likely be reversed if tariff data were collected and included in the analysis.

Because affiliate sales are likely to be influenced by exports and therefore to be determined endogenously, the authors report 2SLS estimates for the Swedish data. Both the OLS and 2SLS estimates suggest a definite complementary relationship between exports and affiliate sales. The estimated coefficients from 2SLS are larger than those from OLS, a contrast to results cited from Swedenborg's work. The 2SLS representation is problematic, though, due to the difficulty of specifying a variable that determines affiliate sales but does not belong in the export equation too. The authors rely on a dummy variable for membership in the EC, a choice that seems less easily justified than a measure directed at the investment process, such as taxes.

The time-series estimates are based on a different functional form, where the change in exports is regressed on the level of affiliate sales as well as the change in affiliate sales. The estimated coefficients for the change in affiliate sales are smaller than those obtained in either the OLS or 2SLS cross-sectional estimates. A potential caution in interpreting the time-series results is that the estimated relationship between exports and affiliate sales may instead be due to a common third factor operating over the period, such as inflation or technical innovation.

The authors are to be commended for reporting the full set of estimated equations in the appendix, including the intercepts obtained, the number of observations available, and other details frequently omitted in empirical work. As noted by the authors, several negative intercepts suggest that the estimated equation may rest on a misspecified functional form or the omission of some other critical variable. Because the full set of results is reported, the reader can evaluate how pervasive this problem is.

The U.S. estimates are based on much finer industry breakdowns than has been possible in previous work, due to the availability of the 1982 benchmark survey of U.S. direct foreign investment abroad. This disaggregation offers the potential advantage of avoiding combining several disparate types of activity together into a single group. Only OLS cross-sectional results are reported in this section of the chapter; they do not suggest as strong a complementary relationship as found in the Swedish data, but neither do they yield many cases of significant substitutability. The mixed outcome is similar in some respects to what Horst found in earlier work. Because heteroskedasticity often can be a problem in cross-sectional studies, some indication of its significance 
here is warranted. However, given the imprecision of many of the industry estimates reported, any adjustment may not be a high priority.

This more diaggregated data set also was used to see if greater U.S. affiliate sales in a foreign country reduced exports to that country from countries other than the United States. The effect of affiliate sales was positive and often statistically significant. This unexpected result again suggests that potential problems of misspecification exist. It may even raise the unsettling possibility that the relationship differs across countries and that cross-sectional analysis is inappropriate. In an analysis based on more aggregate industry groups, the authors were able to consider additional variables, such as the role of minority affiliates, whose importance differs substantially across countries. Those results suggest that in some industries minority operations represent a way to gain market access at the expense of foreign competitors. They also indicate that many possibilities remain in developing a more complete picture of the link between exports and foreign affiliate production. 